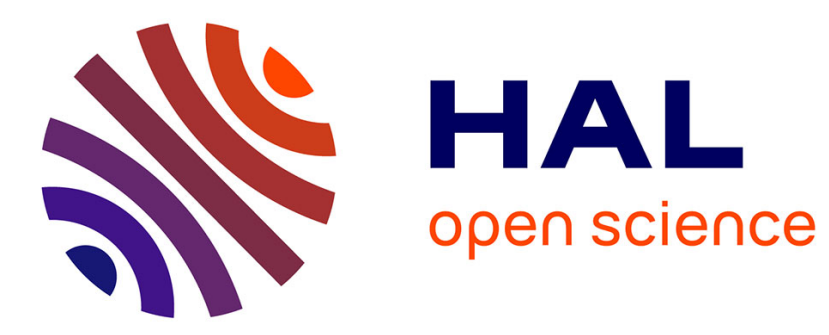

\title{
Low Energy Monopropellants Based on the Guanylurea Cation
}

\author{
Thomas Klapoetke, Carlos Sabate, Jörg Stierstorfer
}

\section{To cite this version:}

Thomas Klapoetke, Carlos Sabate, Jörg Stierstorfer. Low Energy Monopropellants Based on the Guanylurea Cation. Journal of Inorganic and General Chemistry / Zeitschrift für anorganische und allgemeine Chemie, 2009, 636 (1), pp.163. 10.1002/zaac.200900330 . hal-00518305

\section{HAL Id: hal-00518305 https://hal.science/hal-00518305}

Submitted on 17 Sep 2010

HAL is a multi-disciplinary open access archive for the deposit and dissemination of scientific research documents, whether they are published or not. The documents may come from teaching and research institutions in France or abroad, or from public or private research centers.
L'archive ouverte pluridisciplinaire HAL, est destinée au dépôt et à la diffusion de documents scientifiques de niveau recherche, publiés ou non, émanant des établissements d'enseignement et de recherche français ou étrangers, des laboratoires publics ou privés. 


\section{Low Energy Monopropellants Based on the Guanylurea Cation}

\begin{tabular}{|r|l|}
\hline Journal: & Zeitschrift für Anorganische und Allgemeine Chemie \\
\hline Manuscript ID: & zaac. 200900330 \\
\hline Wiley - Manuscript type: & Article \\
\hline Date Submitted by the \\
Author: & 07-Jul-2009 \\
\hline Complete List of Authors: & $\begin{array}{l}\text { Klapoetke, Thomas; LMU Munich, Chemistry and Biochemistry } \\
\text { Sabate, Carlos; LMU Munich, Chemistry and Biochemistry } \\
\text { Stierstorfer, Jörg; LMU Munich, Chemistry }\end{array}$ \\
\hline Keywords: & Energetics, Guanylurea, X-ray diffraction, DFT calculations \\
\hline &
\end{tabular}

\section{(1) ScholaroNE" \\ Manuscript Central}


FULL PAPER

DOI: 10.1002/zaac.200((will be filled in by the editorial sttaff))

\title{
Low Energy Monopropellants Based on the Guanylurea Cation
}

\author{
Thomas M. Klapötke, ${ }^{*[a]}$ and Carles Miró Sabaté ${ }^{[a]}$
}

Keywords: Guanylurea / Energetic / X-ray diffraction / DFT calculations

\begin{abstract}
Reaction of cyanoguanidine (3) with hydrochloric, sulphuric, nitric or perchloric acids yielded guanylurea chloride (4), sulphate (5), nitrate (6) and perchlorate (7). 4 and 5 were reacted further to form a new family of energetic salts based on the guanylurea cation and azide (8a), 5-nitrotetrazolate (9), 5 -aminotetrazolate $(\mathbf{1 0})$, picrate $(\mathbf{1 1})$ and 5,5'-azotetrazolate (12a) anions. The water of hydration in compounds $\mathbf{8 a}$ and 12a was eliminated by heating under vacuum yielding the anhydrous salts $\mathbf{8 b}$ and $\mathbf{1 2 b}$. All materials were characterized by means of elemental analysis, mass spectrometry (MS) and vibrational (IR, Raman) and NMR $\left({ }^{1} \mathrm{H},{ }^{13} \mathrm{C}, 14 / 15 \mathrm{~N}\right.$ and ${ }^{35} \mathrm{Cl}$ ) spectroscopy. Additionally, the crystal structures of 4, 7, 8a and $\mathbf{1 0}$ were determined by low temperature X-ray measurements (4, 7 and 8a: Monoclinic, $P 2{ }_{1} / c$; 10: Monoclinic, $P 21$ ). The thermal behavior of $\mathbf{6 - 1 2}$ was assessed by DSC measurements and their heats of formation was calculated on the basis of the electronic energies of the ions using the MP2 method. In addition, the sensitivity to shock, friction and
\end{abstract}

\section{Introduction}

The synthesis of energetic materials has been a topic of considerable interest specially over the last years. ${ }^{[1]}$ Much work has dedicated its attention towards the synthesis of azole-based energetic salts ${ }^{[1 \mathrm{f}-1 \mathrm{j}, 2]}$ and the scanning of different combinations of anions and cations. ${ }^{[3]}$ The impact on properties of new energetic compounds in view of the different cations and anions provides substantial knowledge. For example, combination with ions with high nitrogen contents results in endothermic (or little exothermic) compounds, whereas well oxygen balanced compounds have often the best performance or for example, dinitramide salts have generally lower melting points and thermal stabilities than analogous nitrate salts.

In the recent past, we reported on new neutral energetic materials based on biuret $(\mathbf{1}),{ }^{[4]}$ which have adequate performance values, however as observed for urea, energetic compounds based on $\mathbf{1}$ are relatively labile (e.g., dinitrobiuret decomposes in protic solvents). Different studies have given credit for the higher stability of salts with guanidinium cations (i.e., guanidinium, amino-, diamino- and triaminoguanidinium) in respect to urea-based compounds. In this context, the parent 2 (guanylurea, GU), which can be seen as the monoimine of 1 should have a better stability due to the guanidine moiety. Although salts of $\mathbf{2}$ were already reported as early as 1933, ${ }^{[5]}$ a synthesis for the free acid (2) did not appear until 1942. ${ }^{[6]}$ Complexes of 2 have been reported to have fungicide ${ }^{[7]}$ and antitumor (i.e., with $\mathrm{Pt})^{[8]}$ properties and recently there has been

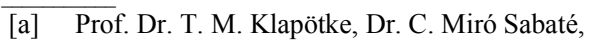
Department of Chemistry and Biochemistry, Energetic Materials Research, Ludwig-Maximilian University Butenandstr. 5-13, D-81377, Munich. Fax: (+49)89-2180-77492

E-mail: tmk@cup.uni-muenchen.de

Calculated IR and Raman frequencies, X-ray, electronic energies and energetic tables and a description of the general method used here are available on the WWW under http://www.eurjic.org/ or from the author.

\begin{abstract}
electrostatic discharge of all materials was measured by submitting the compounds to standard (BAM) tests. The detonation pressures $(P)$ and velocities $(D)$ were calculated from the energies of formation using the EXPLO5 code (6: $P$ $=17.4 \mathrm{GPa}, D=7004 \mathrm{~m} \mathrm{~s}^{-1}$; 8a: $P=20.6 \mathrm{GPa}, D=7880 \mathrm{~m} \mathrm{~s}^{-1}$; 8b: $P=16.9 \mathrm{GPa}, D=7289 \mathrm{~m} \mathrm{~s}^{-1}$; 9: $P=20.3 \mathrm{GPa}, D=7439 \mathrm{~m}$ $\mathrm{s}^{-1}$; 10: $P=18.4 \mathrm{GPa}, D=7530 \mathrm{~m} \mathrm{~s}^{-1}$; 11: $P=19.7 \mathrm{GPa}, D=$ $7152 \mathrm{~m} \mathrm{~s}^{-1}$; 12a: $P=24.3 \mathrm{GPa}, D=8222 \mathrm{~m} \mathrm{~s}^{-1}$ and $7: P=23.3$ $\mathrm{GPa}, D=8115 \mathrm{~m} \mathrm{~s}^{-1}$ ). Lastly, the long term stability of 12a was assessed and the ICT code was used to predict the decomposition gases. Most materials decompose giving large amount of environmentally friendly gases and their performance values classify them as new insensitive lowenergy monopropellants.
\end{abstract}

(ㄷ) WILEY-VCH Verlag GmbH \& Co. KGaA, 69451 Weinheim, Germany, 2007) considerable interest in the use of $\mathbf{2}$ as a bidentate ligand for coordination chemistry ${ }^{[9]}$ although alkylated derivatives had already been used before. ${ }^{[10]}$ Guanidines have also attracted people's interest for the synthesis of energetic materials ${ }^{[11]}$ and guanylurea dinitramide (FOX-12) has recently been described in several patents ${ }^{[12]}$ as a new promising energetic compound for lowsensitivity munitions in propellants and explosives applications. The compound can be conveniently synthesized by a metathesis reaction of commercially available guanylurea sulphate (5) with ammonium dinitramide in high yield. ${ }^{[13]}$ However, a cheap source of the dinitramide anion $\left.\left(\mathrm{N}_{(} \mathrm{NO}_{2}\right)_{2}\right)$ is not available in the open literature, which makes the production of FOX-12 rather expensive.<smiles>NC(=O)NC(N)=O</smiles>
1<smiles>N=C(N)NC(N)=O</smiles>
2
Scheme 1. Formula structures of biuret (1) and guanylurea (2).

The formal replacement of one of the oxygen atoms in $\mathbf{1}$ by an amino group in salts of $\mathbf{2}$ should allow for the formation of extensive hydrogen-bonding networks in the solid state. Such networks help to stabilize the material considerably and are, for example, responsible for the low sensitivitiy of 1,1-amino-2,2dinitroethene (FOX-7). ${ }^{[14]}$ Ionic energetic materials based on guanidines are also known to form strong hydrogen-bonding networks and can show remarkable stability and considerable insensitivity to physical stimuli. Salts such as ammonium nitrate (AN), perchlorate (AP) and dinitramide (ADN) are commonly used as oxidizers in explosive and currently used propellant mixtures to compensate for the negative oxygen balances and boost the performance. In addition, ionic energetic materials tend to exhibit 
lower vapor pressure (essentially eliminating the risk of exposure through inhalation) than similar neutral non-ionic analogues. ${ }^{[15]}$ Surprisingly, regardless of the potential of guanylurea chloride monohydrate ${ }^{[16]}$ and guanylurea sulphate (5) as starting materials for the synthesis of energetic compounds and the interesting energetic properties of the dinitramide salt, the latter remains as the only report of a guanylurea salt, which has been considered for energetic applications. The nitrate salt (6) had been either only mentioned $^{[17]}$ or described in the non-international literature ${ }^{[18]}$ prior to our studies. ${ }^{[19]}$ Thus, we decided to investigate the potential of the $\mathrm{GU}^{+}$cation to form energetic salts in combination with highly endothermic anions $\left(\mathrm{N}_{3}^{-},\left[\mathrm{N}_{4} \mathrm{C}-\mathrm{NO}_{2}\right]^{-},\left[\mathrm{N}_{4} \mathrm{C}-\mathrm{NH}_{2}\right]^{-}\right.$and $\left.\left[\mathrm{N}_{4} \mathrm{C}-\mathrm{N}=\mathrm{N}-\mathrm{CN}_{4}\right]^{2-}\right)$ and oxygen-rich anions $\left(\left[\mathrm{N}_{4} \mathrm{C}-\mathrm{NO}_{2}\right]^{-}\right.$and picrate). The detonation parameters of the new compounds as well as those of formulations with an oxidizer (AN and $\mathrm{ADN}$ ) were calculated. Lastly, due to the increasing environmental concern the gases formed upon decomposition of the compounds where predicted using a computer code.

\section{Results and Discussion}

\section{Synthesis}

In order to synthesize the guanylurea cation $\left(\mathrm{GU}^{+}\right)$, cyanoguanidine (3) was hydrolized and protonated with a strong acid (i.e., hydrochloric or sulfuric acid) to form guanylurea chloride (4) or gunylurea sulfate (5), as indicated in Scheme 2. Alternatively, other strong acids such as nitric acid or perchloric acid can also be used rendering the energetically interesting nitrate (6) and perchlorate (7) salts. Metathetical reactions of $\mathbf{4}$ with a silver or sodium salt, lead to the formation of the azide (8a) and 5,5' -azotetrazolate (12a) salts, which form as the hydrated species. The water of crystallization can be conviniently removed by heating the compounds under vacuum rendering the anhydrous materials $(\mathbf{8 b}$ and $\mathbf{1 2 b})$. On the other hand, reaction of the sulfate salt (5) with a suitable barium tetrazolate salt, allowed us to isolate the 5-nitrotetrazolate (9) and 5-aminotetrazolate (10) salts, after separating the precipitated barium sulfate. Due to the high insolubility of the picrate salt (11), this could be prepared by direct reaction between the chloride salt (4) and picric acid. All materials were characterized by means of elemental analysis, mass spectrometry (MS) and vibrational (IR, Raman) and NMR $\left({ }^{1} \mathrm{H}\right.$, ${ }^{13} \mathrm{C}$ and/or ${ }^{15} \mathrm{~N}$ NMR) spectroscopy. Additionally, the crystal structures of $\mathbf{4 , 7 , 8 a}$ and 10 were determined.

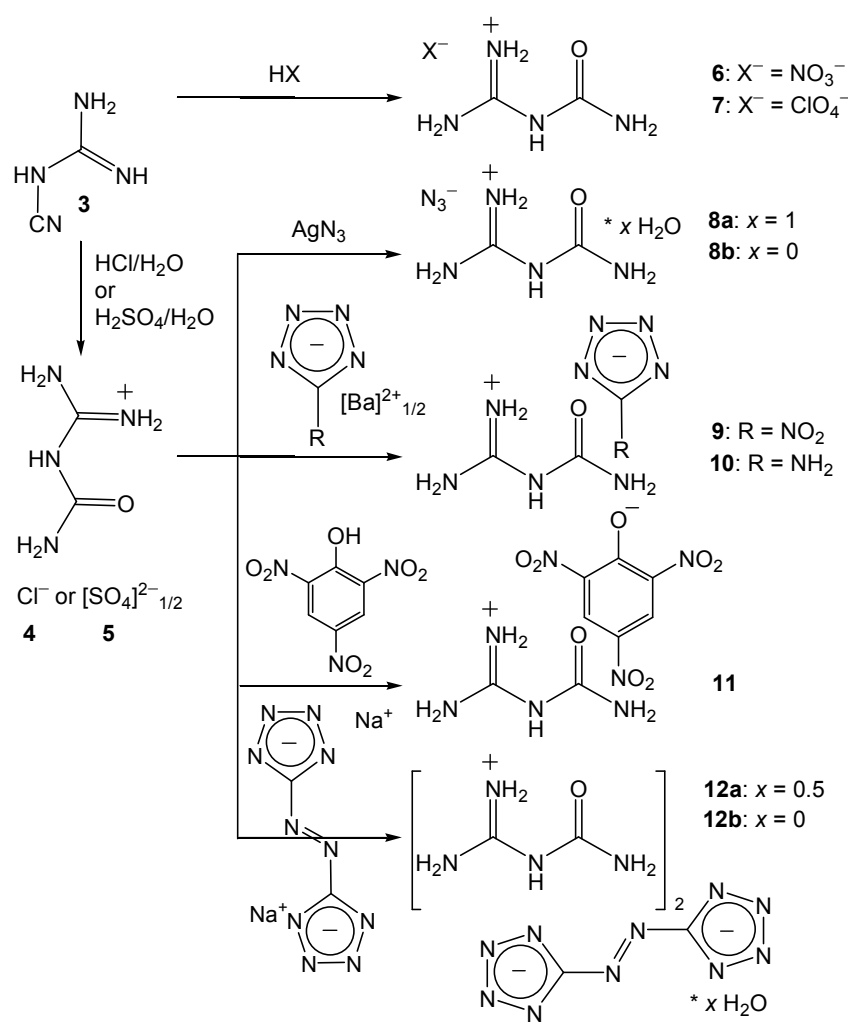

Scheme 2. Synthesis of guanylurea salts 4-12.

Lastly, compounds 4-10 were isolated as colorless powders, which are readily soluble in water and other polar solvents such as DMSO, DMF or short chain alcohols, whereas salts 11, 12a and 12b are only slightly soluble in boiling water, moderately soluble in DMSO or DMF and completely insoluble in any other common solvent.

\section{Vibrational and NMR Spectroscopy}

Computational Methods. All quantum chemical calculations (see also "Thermal and Energetic Properties" section) were carried out with the Gaussian03W software package. ${ }^{[20]}$ Vibrational (IR and Raman) frequencies of the guanylurea cation were calculated using Becke's B3 three parameter hybrid function with an LYP correlation function (B3LYP) $)^{[21]}$ and were scaled by a factor of 0.9614 as described by Radom et al. ${ }^{[22]}$ For all atoms in all calculations, the correlation consistent polarized double-zeta basis set cc-pVDZ was used. ${ }^{[23,24]}$

All salts were qualitatively identified by IR and Raman spectroscopy. The bands of the corresponding anions can be easily identified due to the characteristic fingerprints. In the Raman spectra they are found at $1054 \mathrm{~cm}^{-1}\left(\mathrm{NO}_{3}^{-}, 6\right), 932$ and $461 \mathrm{~cm}^{-1}$ $\left(\mathrm{ClO}_{4}^{-}, 7\right), \mathrm{ca} .1340 \mathrm{~cm}^{-1}\left(\mathrm{~N}_{3}^{-}, \mathbf{8 a}\right.$ and 8b) $, 1422,1064$ and 1032 $\mathrm{cm}^{-1}\left(\left[\mathrm{~N}_{4} \mathrm{C}-\mathrm{NO}_{2}\right]^{-}, \mathbf{9}\right), 1714 \mathrm{~cm}^{-1}\left(\left[\mathrm{~N}_{4} \mathrm{C}-\mathrm{NH}_{2}\right]^{-}, \mathbf{1 0}\right), 1316 \mathrm{~cm}^{-1}$ $\left(\left[\left(\mathrm{NO}_{2}\right)_{3} \mathrm{Ph}-\mathrm{O}\right]^{-}\right.$, 11) and at ca. 1480 and $1380 \mathrm{~cm}^{-1}$ $\left(\left[\mathrm{N}_{4} \mathrm{C}-\mathrm{N}=\mathrm{N}-\mathrm{CN}_{4}\right]^{2-}, \mathbf{1 2 a}\right.$ and 12b). The stretches of the anions are, as expected, of lower intensity in the IR spectra and observed at $1385 \mathrm{~cm}^{-1}\left(\mathrm{NO}_{3}^{-}, \mathbf{6}\right), 1089 \mathrm{~cm}^{-1}\left(\mathrm{ClO}_{4}^{-}, 7\right), \mathrm{ca} .2040 \mathrm{~cm}^{-1}\left(\mathrm{~N}_{3}^{-}, \mathbf{8 a}\right.$ and 8b), 1420, 1060 and $1022 \mathrm{~cm}^{-1}\left(\left[\mathrm{~N}_{4} \mathrm{C}-\mathrm{NO}_{2}\right]^{-}, 9\right), 1701 \mathrm{~cm}^{-1}$ $\left(\left[\mathrm{N}_{4} \mathrm{C}-\mathrm{NH}_{2}\right]^{-}, \mathbf{1 0}\right), 1563 \mathrm{~cm}^{-1}\left(\left[\left(\mathrm{NO}_{2}\right)_{3} \mathrm{Ph}-\mathrm{O}\right]^{-}, \mathbf{1 1}\right)$ and at $c a .1400$ and $760 \mathrm{~cm}^{-1}\left(\left[\mathrm{~N}_{4} \mathrm{C}-\mathrm{N}=\mathrm{N}-\mathrm{CN}_{4}\right]^{2-}, \mathbf{1 2 a}\right.$ and 12b). ${ }^{[1 \mathrm{~b}, 1 \mathrm{~h}, 11 \mathrm{c}, 19,25]}$

The vibrational (both IR and Raman) frequencies of the $\mathrm{GU}^{+}$cation were calculated and scaled as described above. Table S1 of the supporting information contains tabulated the calculated, scaled 
and measured frequencies of the cation in salts 6-12. The measured frequencies have been taken as a rough average of the observed signals in the IR and Raman spectra of all compounds. As expected, the calculated shifts at the highest wave numbers do not find a match in the experimental values. However, the rest of the calculated values find reasonably good agreement in the observed frequencies. $\mathrm{NH}$ stretching bands are very intense in the IR spectra and found in the range from $c a .3200$ to $3400 \mathrm{~cm}^{-1}$. The stretching vibrations of the urea $(\mathrm{C}=\mathrm{O})$ and guanidine $(\mathrm{C}=\mathrm{N})$ moieties are coupled to deformation modes of the amino groups and found at $c a$. 1740 and $1645 \mathrm{~cm}^{-1}$, respectively. The range $1600-900 \mathrm{~cm}^{-1}$ is mainly dominated by deformation modes of the three $\mathrm{NH}_{2}$ groups and $\mathrm{C}-\mathrm{O}$ and $\mathrm{C}-\mathrm{N}$ stretching modes. The rocking vibrations of the guanidine and urea moieties are active both in the IR and Raman spectra of the compounds and found at $c a .710 \mathrm{~cm}^{-1}$. Below 700 $\mathrm{cm}^{-1}$ the spectra are again dominated by many in-plane and out-ofplane bending vibrations.

${ }^{1} \mathrm{H}$ NMR of the compounds in DMSO- $\mathrm{d}_{6}$ shows (in general) well resolved resonances for the hydrogen atoms in the $\mathrm{GU}^{+}$cation. They are observed at $c a .10(\mathrm{NH}), 8\left(\mathrm{NH}_{2}^{+}\right)$and $7\left(\mathrm{NH}_{2}\right)$ ppm as broad singulets. In the ${ }^{13} \mathrm{C}$ NMR the guanidine $\left(\mathrm{CN}_{3}\right)$ and the urea $\left(\mathrm{C}(\mathrm{O}) \mathrm{N}_{2}\right)$ carbon atoms have similar shifts at $c a .155 \mathrm{ppm}$ and can not be differentiated. Due to the quadrupol broadening observed in the ${ }^{14} \mathrm{~N}$ NMR of the compounds only highly symmetrical anions could be observed. Thus the resonance of the nitrate anion was found at $-5 \mathrm{ppm}$, whereas the azide anion showed the two common resonances for ionic azides at $c a .-140$ and $-270 \mathrm{ppm}$, the nitrogroup of the 5-nitrotetrazolate anion resonates at $-23 \mathrm{ppm}$ and the nitro-groups of the picrate anion have a broad shift at $-12 \mathrm{ppm}$. In order to observe the resonances of the cation a ${ }^{15} \mathrm{~N}$ NMR (natural abundance) was recorded (Figure 1). Apart from the shifts of the anion the three nitrogen atoms attached to hydrogen atoms have highly negative resonances. The $\mathrm{NH}$ nitrogen atom resonates at the lowest field of all three at $-272 \mathrm{ppm}$ and appears as a doublet, whereas the two different $\mathrm{NH}_{2}$ groups have very similar shifts at $c a$. $-300 \mathrm{ppm}$ and are observed as two overlapping triplets. All three coupling constants $(J)$ have similar values at $c a .90 \mathrm{~Hz}$.

Table 1. Crystal structure solution and refinement for guanylurea salts 4, 7, 8a and $\mathbf{1 0}$

\begin{tabular}{lllll}
\hline Parameter & $\mathbf{4}$ & $\mathbf{7}$ & $\mathbf{8 a}$ & $\mathbf{1 0}$ \\
\hline Empirical formula & $\mathrm{C}_{2} \mathrm{H}_{7} \mathrm{~N}_{4} \mathrm{OCl}$ & $\mathrm{C}_{2} \mathrm{H}_{7} \mathrm{~N}_{4} \mathrm{O}_{5} \mathrm{Cl}$ & $\mathrm{C}_{2} \mathrm{H}_{9} \mathrm{~N}_{7} \mathrm{O}_{2}$ & $\mathrm{C}_{3} \mathrm{H}_{9} \mathrm{~N}_{9} \mathrm{O}$ \\
Formula weight $/ \mathrm{g} \mathrm{mol}^{-1}$ & 138.57 & 202.57 & 163.16 & 187.19 \\
Temperature / K & $100(2)$ & $100(2)$ & $100(2)$ & $100(2)$ \\
Crystal size / mm & $0.25 x 0.10 x 0.10$ & $0.20 x 0.10 x 0.10$ & $0.18 x 0.10 x 0.07$ & $0.30 x 0.10 x 0.05$ \\
Crystal system & Monoclinic & Monoclinic & Monoclinic & Monoclinic \\
Space group & $P 2{ }_{1} / c$ & $P 2_{1} / c$ & $P 2$ & $P 2_{1} / c$ \\
$a / \AA$ & $8.2515(3)$ & $8.0115(2)$ & $8.6403(3)$ & $6.8425(5)$ \\
$b / \AA$ & $10.7121(4)$ & $9.7328(2)$ & $6.6651(2)$ & $4.8514(4)$ \\
$c / \AA$ & $6.7703(3)$ & $9.5770(2)$ & $12.8932(6)$ & $11.943(1)$ \\
$\alpha / \circ$ & 90 & 90 & 90 & 90 \\
$\beta / \circ$ & $108.53(1)$ & $105.895(2)$ & $102.29(1)$ & $96.22(1)$ \\
$\gamma / \circ$ & 90 & 90 & 90 & 90 \\
$V_{\mathrm{UC}} / \AA$ & $567.4(9)$ & $718.21(3)$ & $725.4(6)$ & $394.1(3)$ \\
\hline
\end{tabular}

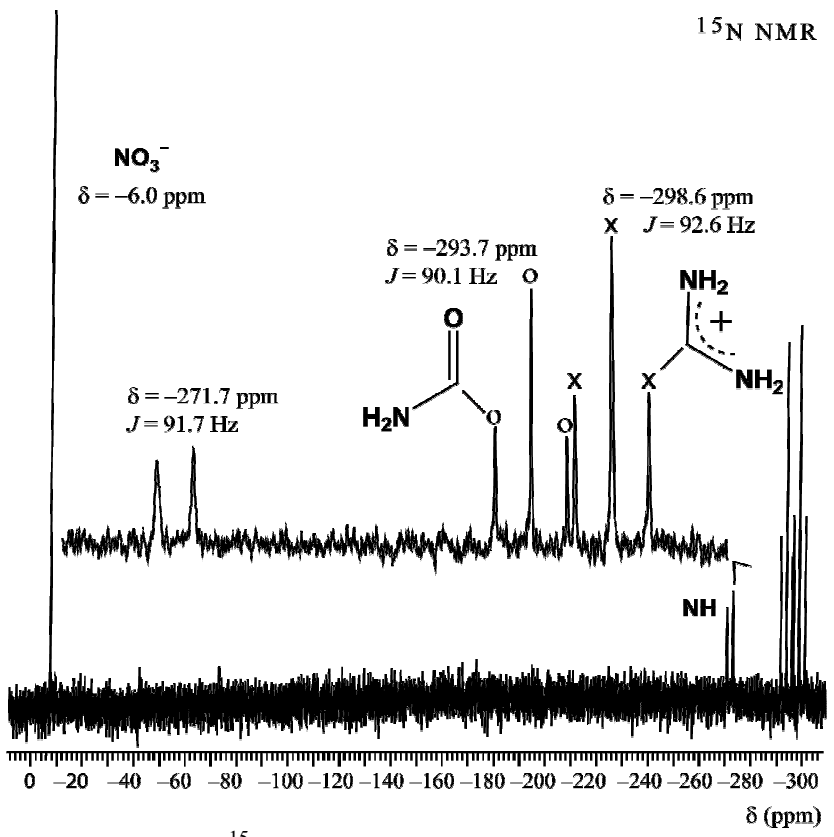

Figure 1. Coupled ${ }^{15} \mathrm{~N}$ NMR of the guanylurea cation in guanylurea nitrate (6).

\section{Crystal Structures}

Single crystals of compounds $4,7,{ }^{[19]} \mathbf{8 a}$ and $\mathbf{1 0}$, suitable for $\mathrm{X}$-ray diffraction analysis, were grown as described in the experimental section. The X-ray crystallographic data sets were collected on an Oxford Diffraction Xcalibur 3 diffractometer equipped with a CCD detector using the CrysAlis CCD software. ${ }^{[26]}$ All data were collected using graphite-monochromated Mo $\mathrm{K} \alpha$ radiation $(\lambda=0.71073 \AA)$. The data reductions were performed with the CrysAlis RED software, ${ }^{[27]}$ and no absorption corrections were applied to data sets collected for any of the compounds. All structures were solved by direct methods using the suit of programs (SHELXS-97 and SIR92) available in the Wingx package, ${ }^{[28-31]}$ refined by means of full-matrix least-squares procedures using SHELXL-97 and finally checked using the program PLATON. ${ }^{[32]}$ All non-hydrogen atoms were refined anisotropically. For all compounds all hydrogen atoms were located from difference Fourier electron-density maps and refined isotropically. The crystallographic data and refinement have been summarized in Table 1 . Table 2 shows a summary of the bond distances and angles for the $\mathrm{GU}^{+}$cation in the different compounds. The hydrogen-bonding geometries have been collected in the supporting information Table S2, whereas Tables S3 to S6 contain a full record of the graph-sets found in the structures. Further information concerning the crystal structure determinations in CIF format has been deposited at the Cambridge Crystallographic Data Centre. ${ }^{[33]}$ 


\begin{tabular}{|c|c|c|c|c|}
\hline $\bar{Z}$ & 4 & 4 & 4 & 2 \\
\hline$\rho_{\text {calc }} / \mathrm{g} \mathrm{cm}^{-3}$ & 1.622 & 1.873 & 1.494 & 1.577 \\
\hline$\mu / \mathrm{mm}^{-1}$ & 0.575 & 0.527 & 0.127 & 0.126 \\
\hline$F(000)$ & 288 & 416 & 344 & 196 \\
\hline$\theta$ range $/ \circ$ & $3.70-25.99$ & $4.19-26.00$ & $3.90-26.00$ & $4.30-30.11$ \\
\hline \multirow[t]{3}{*}{ Index ranges } & $-10 \leq \mathrm{h} \leq 10$ & $-9 \leq \mathrm{h} \leq 11$ & $-10 \leq h \leq 10$ & $-9 \leq \mathrm{h} \leq 9$ \\
\hline & $-13 \leq \mathrm{k} \leq 13$ & $-12 \leq \mathrm{k} \leq 11$ & $-8 \leq \mathrm{k} \leq 8$ & $-6 \leq \mathrm{k} \leq 6$ \\
\hline & $-8 \leq 1 \leq 8$ & $-11 \leq 1 \leq 11$ & $-15 \leq 1 \leq 15$ & $-16 \leq 1 \leq 16$ \\
\hline Reflections collected & 5567 & 5373 & 7031 & 5346 \\
\hline Independent reflections & $1115\left(\mathrm{R}_{\mathrm{int}}=0.0232\right)$ & ) $1397\left(R_{\text {int }}=0.0214\right.$ & $1421\left(\mathrm{R}_{\mathrm{int}}=0.0194\right)$ & $1281\left(\mathrm{R}_{\mathrm{int}}=0.0335\right)$ \\
\hline Data/Restraints/Parameters & $1115 / 0 / 101$ & $1397 / 0 / 137$ & $1421 / 0 / 137$ & $1281 / 0 / 154$ \\
\hline Goodness-of-fit on $F^{2}$ & 1.089 & 1.098 & 1.106 & 0.831 \\
\hline $\mathrm{R}_{1}[F>4 \sigma(F)]$ & 0.0209 & 0.0257 & 0.0261 & 0.0287 \\
\hline $\mathrm{R}_{1}$ (all data) & 0.0274 & 0.0286 & 0.0325 & 0.0516 \\
\hline $\mathrm{wR}_{2}[F>4 \sigma(F)]$ & 0.0494 & 0.0706 & 0.0721 & 0.0571 \\
\hline $\mathrm{wR}_{2}$ (all data) & 0.0527 & 0.0718 & 0.0764 & 0.0585 \\
\hline
\end{tabular}

The crystal structure of the perchlorate salt (7) has been previously reported in our group ${ }^{[19]}$ and is only showed here for comparison purposes. Figure 2 shows the asymmetric unit of the compound, where the lone pair of the $\mathrm{NH}_{2}$ nitrogen atom (N1) shows delocalization over to the carbonyl group, as reflected by a substantially shorter $\mathrm{C} 1-\mathrm{N} 1$ distance $(\sim 1.33 \AA)$ in comparison to the $\mathrm{C} 1-\mathrm{N} 2$ bond $(\sim 1.40 \AA)$. The $\mathrm{C} 1-\mathrm{N} 1$ bond character falls inbetween that of a classical $\mathrm{C} 1-\mathrm{N} 1$ single bond $(1.47 \AA)$ and that of a C1=N1 double bond $(1.22 \AA) .{ }^{[34]}$

Table 2. Selected bond distances $(\AA)$ and angles $\left({ }^{\circ}\right)$ for guanylurea salts 4, 7, 8a and 10.

\begin{tabular}{lllll}
\hline Distances & $\mathbf{4}$ & $\mathbf{7}$ & $\mathbf{8 a}$ & $\mathbf{1 0}$ \\
\hline N1-C1 & $1.331(2)$ & $1.330(2)$ & $1.332(1)$ & $1.343(2)$ \\
C1-O1 & $1.234(2)$ & $1.233(2)$ & $1.227(1)$ & $1.227(2)$ \\
C1-N2 & $1.398(2)$ & $1.398(2)$ & $1.400(1)$ & $1.391(2)$ \\
N2-C2 & $1.357(2)$ & $1.357(2)$ & $1.360(1)$ & $1.359(2)$ \\
C2-N3 & $1.312(2)$ & $1.317(2)$ & $1.313(1)$ & $1.314(2)$ \\
C2-N4 & $1.323(2)$ & $1.319(2)$ & $1.319(1)$ & $1.318(2)$ \\
\hline Angles & $\mathbf{4}$ & $\mathbf{7}$ & $\mathbf{8 a}$ & $\mathbf{1 0}$ \\
\hline N1-C1-O1 & $124.8(1)$ & $124.4(1)$ & $124.1(1)$ & $124.1(2)$ \\
N1-C1-N2 & $112.9(1)$ & $113.6(1)$ & $114.2(1)$ & $112.3(2)$ \\
O1-C1-N2 & $122.2(1)$ & $122.0(1)$ & $121.5(1)$ & $123.5(2)$ \\
C1-N2-C2 & $126.7(1)$ & $126.0(1)$ & $125.5(1)$ & $125.9(2)$ \\
N2-C2-N3 & $122.2(1)$ & $121.0(1)$ & $121.2(1)$ & $120.7(2)$ \\
N2-C2-N4 & $116.2(1)$ & $117.8(1)$ & $117.2(1)$ & $117.6(2)$ \\
N3-C2-N4 & $121.4(1)$ & $121.2(2)$ & $121.4(1)$ & $121.6(2)$ \\
\hline
\end{tabular}
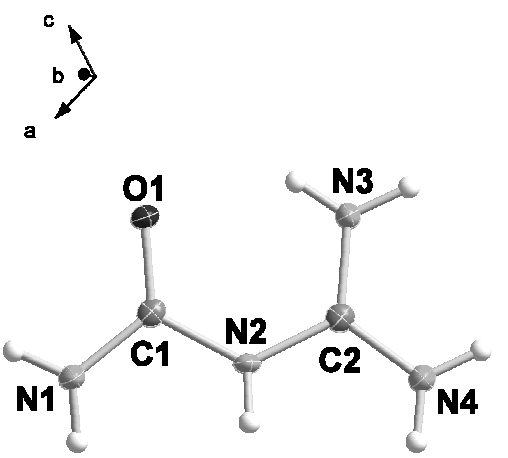

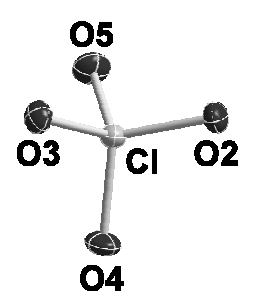

Figure 2. Asymmetric unit of 7 with the labelling scheme. Selected bond distances $(\AA)$ and angles $\left({ }^{\circ}\right)$ for the $\mathrm{ClO}_{4}^{-}$anion: $\mathrm{Cl}-\mathrm{O} 5=$ $1.432(1), \mathrm{Cl}-\mathrm{O} 2=1.439(1), \mathrm{Cl}-\mathrm{O} 4=1.444(1), \mathrm{Cl}-\mathrm{O} 3=1.461(1)$ $\AA ; \mathrm{O} 5-\mathrm{Cl}-\mathrm{O} 2=110.3(1), \mathrm{O} 5-\mathrm{Cl}-\mathrm{O} 4=110.2(1), \mathrm{O} 2-\mathrm{Cl}-\mathrm{O} 4=$ 110.2(1), O5-Cl-O3 = 109.4(1), O2-Cl-O3 = 108.9(1), O4-Cl-O3 $=107.9(1)^{\mathrm{o}}$.

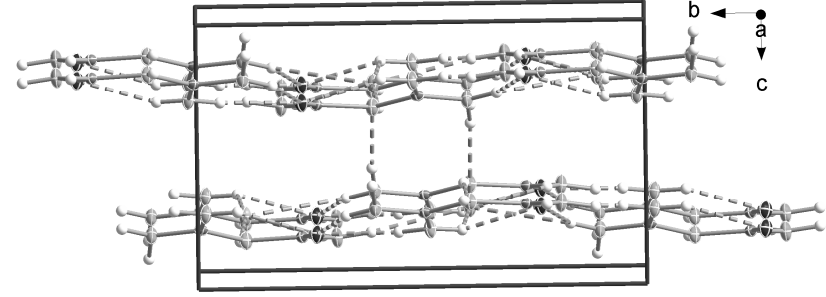

Figure 3. View of the unit cell of compound 4 along the $a$-axis showing the hydrogen-bonding in a layer and between layers (dotted lines).

In contrast to the remainder of the compounds, the $\mathrm{GU}^{+}$cation in $\mathbf{4}$ is not planar. The urea and guanidine moieties are twisted in respect to each other (dihedral angle $\mathrm{C} 2-\mathrm{N} 2-\mathrm{C} 1-\mathrm{O} 1=-15.1(2)^{\circ}$ ). The formation of non-planar layers along the $b$-axis in the unit cell is represented in Figure 3. The "twisted" guanidine amino-group nitrogen atom (N4) joins the layers by forming hydrogen bonds to the chlorine atoms with $\mathrm{N} 4-\mathrm{H} 4 \mathrm{~B} \cdot \bullet \mathrm{Cl}^{\mathrm{iii}}=3.203(1) \AA$ (symmetry code: (iii) $1-\mathrm{x},-\mathrm{y},-\mathrm{z}$ ). Extensive hydrogen-bonding in a layer is found: every chlorine atom forms five hydrogen bonds to four different $\mathrm{GU}^{+}$cations (Figure 4a). Together with the aforementioned hydrogen bond between layers, the coordination via formation of hydrogen bridges around the chlorine atoms is six, describing a distorted pentagonal base pyramid, with distances between donor and acceptor atoms in the range $c a$. 3.15-3.30 $\AA$, well within the sum of the van der Waals radii $\left(r_{\mathrm{N}}+r_{\mathrm{Cl}}=3.30\right.$ $\AA) .{ }^{[35]}$ Graph-set analysis ${ }^{[36]}$ facilitates the description of the complex hydrogen-bonding networks found in the structure of 4 . At the primary level, six D1,1(2), two C1,1(2) and the usual S(6) patterns are identified by RPLUTO. At the secondary level, dimmer $\mathbf{D 3 , 2}(9)$ and $\mathbf{D 3 , 3}(\mathbf{X})(X=11,13)$, chain $\mathbf{C 1 , 2}(\mathbf{X})(X=4,6,8)$ and $\mathbf{C 2 , 2 ( 1 2 )}$ and ring $\mathbf{R 1 , 2 ( 6 )}$ and $\mathbf{R 2 , 4 ( X )}(\mathrm{X}=12,16)$ graph-sets are found. Some of these patterns resemble those of the azide salt $\mathbf{8 a}$ (see below), for example, the R1,2(6) pattern (Figure 4b) is formed by the urea half of the cation (the guanidine half in the azide salt) with $\mathrm{N} 2 \cdots \mathrm{Cl}=3.159(1) \AA$ and $\mathrm{N} 1 \cdots \mathrm{Cl}=3.318(1) \AA$. Other graphsets are characteristic of the chloride salt, such as the $\mathbf{R 2 , 4 ( 1 2 )}$ network formed by the hydrogen bond between layers. 
a)

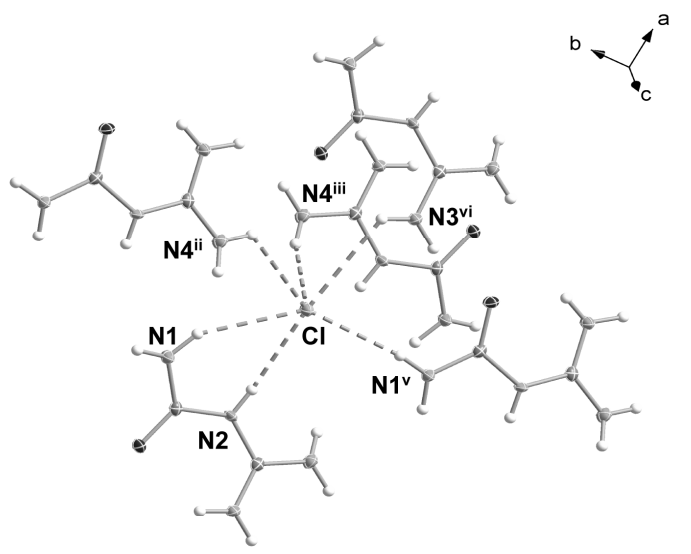

b)

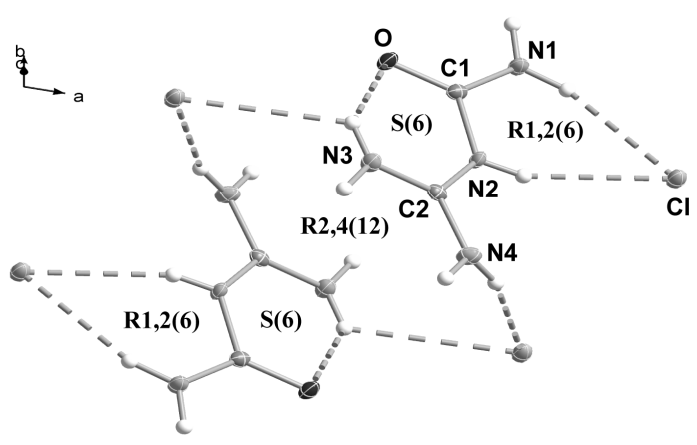

Figure 4. a) Hydrogen-bonding around the chloride anion in the crystal structure of compound $\mathbf{4}$ and b) representative hydrogenbonding networks. Symmetry codes: (ii) $1-\mathrm{x}, 0.5+\mathrm{y}, 0.5-\mathrm{z}$; (iii) $1-$ $\mathrm{x},-\mathrm{y},-\mathrm{z}$; (v) $1-\mathrm{x},-0.5+\mathrm{y}, 0.5-\mathrm{z}$; (vi) $1+\mathrm{x}, \mathrm{y}, \mathrm{z}$.

Guanylurea azide crystallizes as the monohydrate compound (8a) forming the twelve medium-to-strong hydrogen bonds summarized in Table S5, ten of which are normal dimmeric interactions of the type D1,1(2) (primary level). On the other hand, one of the amino group nitrogen atoms in the cation forms one $\mathbf{C 1 , 1 ( 6 )}$ chain graphset with one of the azide nitrogen atoms with a long hydrogen bond $\left(\mathrm{N} 4 \cdot \cdots \mathrm{N} 5^{\mathrm{iii}}=3.342(1) \AA \AA\right.$; symmetry code: (iii) $\left.1-\mathrm{x}, 1-\mathrm{y},-\mathrm{z}\right)$ and the intramolecular hydrogen bond $(\mathrm{N} 3 \cdots \mathrm{O} 1=2.647(1) \AA)$ is described by an $\mathbf{S ( 6 )}$ motif. At the secondary level, most of the hydrogen-bonding networks are described by finite patterns of the type D1,2(3), D2,2(X) $(X=4,5,7,9), \mathbf{D 3 , 2 ( 9 )}$ and $\mathbf{D 3 , 3 ( X )}(\mathrm{X}=$ $11,13)$. However, there exist many $\mathbf{C 1 , 2 ( X )}(X=6,8)$ and $\mathbf{C 2 , 2 ( X )}(\mathrm{X}=6,7,9)$ chain patterns and $\mathbf{R 2 , 1 ( 3 ) , ~ R 1 , 2 ( 6 )}$ and $\mathbf{R 4}, \mathbf{4}(\mathrm{X})(\mathrm{X}=12,16,18)$ graph-sets. Some of these networks are represented in Figure 5. The R1,2(6) motifs are formed between $\mathrm{N}_{4} \mathrm{H}_{2}$, which describes the chain pattern discussed above and $\mathrm{N} 2 \mathrm{H}$ of the cation by interaction to one of the azide anion nitrogen

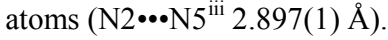

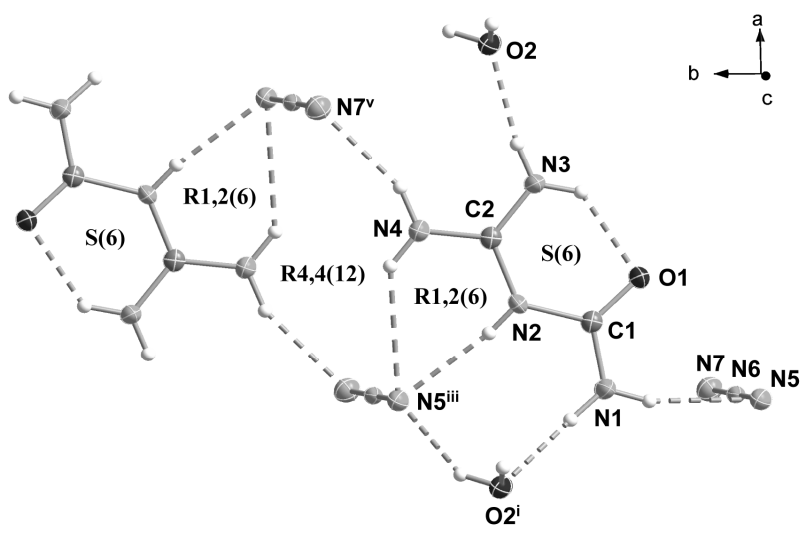

Figure 5. Hydrogen-bonding around the $\mathrm{GU}^{+}$cation in the crystal structure of compound 8a showing the formation of some characteristic graph-sets. Selected bond distances $(\AA)$ and angles ${ }^{\circ}$ ) for the $\mathrm{N}_{3}^{-}$anion: N6-N5 = 1.182(1), N6-N7 = 1.176(1) $\AA$; N5$\mathrm{N} 6-\mathrm{N} 7=178.7(1)^{\circ}$.

Two cations placed on contiguous layers interact over "azidebridges" to form an $\mathbf{R 4 , 4 ( 1 2 )}$ graph-set, again via the hydrogen bond between $\mathrm{N} 4$ and $\mathrm{N} 5^{\mathrm{iii}}$ and also between $\mathrm{N} 4$ and $\mathrm{N} 7^{\mathrm{v}}\left(\mathrm{N} 4 \cdot \cdots \cdot \mathrm{N} 7^{\mathrm{v}}\right.$ $=3.013(1) \AA$; symmetry code: (v) $1+x, 1+y, z)$. In the unit cell (Figure 6) there are layers of cations, which are approximately parallel to the $a$-direction whereas the azide anions are parallel to the $c$-axis and, thus, perpendicular to the cations. The crystal water molecules act as hydrogen bond donors joining the anions $\left(\mathrm{O} 2 \cdots \mathrm{N}^{\mathrm{vii}}=2.826(1) \AA\right.$ and $\mathrm{O} 2 \cdots \bullet^{\mathrm{N}} 5^{\text {viii }}=2.826(1) \AA$; symmetry codes: (vii) $2-\mathrm{x}, 0.5+\mathrm{y}, 0.5-\mathrm{z}$; (viii) $2-\mathrm{x}, 1-\mathrm{y},-\mathrm{z}$ ) and as hydrogen bond acceptors joining the cations $(\mathrm{N} 3 \cdots \mathrm{O} 2=2.824(1) \AA$ and $\mathrm{N} 1 \cdots \mathrm{O} 2^{\mathrm{i}} 2.951(1) \AA$; symmetry code: (i) $\left.-1+\mathrm{x}, \mathrm{y}, \mathrm{z}\right)$ and forming a complex three dimensional hydrogen-bonded network.

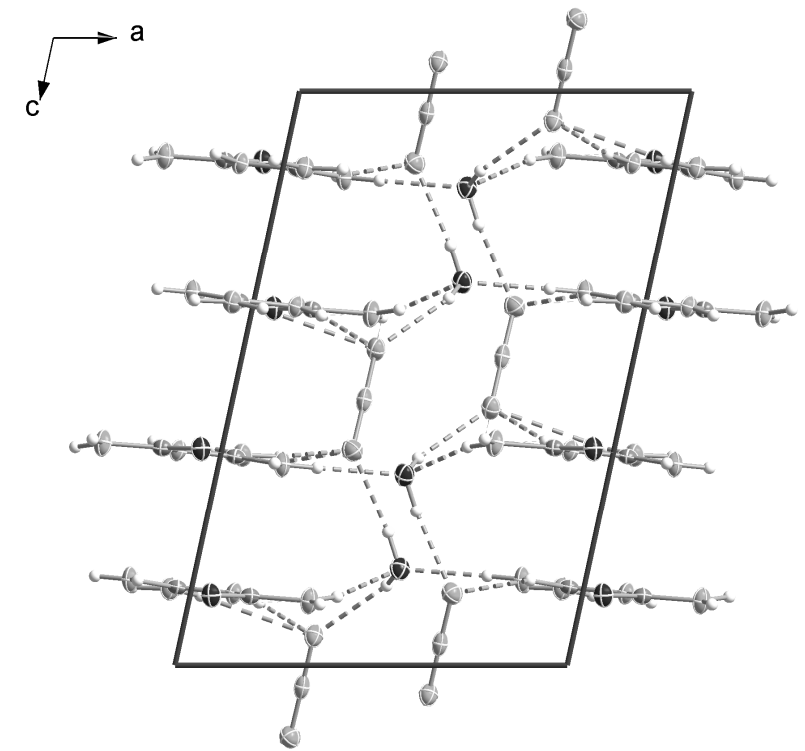

Figure 6. View of the unit cell of compound 8a along the $b$-axis showing the hydrogen-bonding in the structure (dotted lines).

Figure 7a shows the asymmetric unit with the labelling scheme for salt 10. In contrast to 5 -aminotetrazolium salts (i.e., positively charged tetrazole ring) where the amino group is approximately coplanar with the tetrazole ring, the amino group in the 5aminotetrazolate anion has a marked $\mathrm{sp}^{3}$ character (e.g., $\mathrm{C}-\mathrm{NH}_{2}$ distance in 5-aminotetrazolium nitrate is with 1.308(2) $\AA$, much shorter than that found in $\mathbf{1 0}$ for which $\mathrm{C} 3-\mathrm{N} 7=1.380(2) \AA),{ }^{[37 \mathrm{a}]}$ keeping in with alkali metal salts containing the same anion. ${ }^{[37 b]}$ The non-planarity of the anion accounts for the non-formation of layers in the structure as shown in Figure $7 \mathrm{~b}$. The amino groups in 
the guanylurea cation are $\mathrm{sp}^{2}$ hybridized and thus the structure of the cation is planar (dihedral angle $\mathrm{N} 1-\mathrm{C} 1-\mathrm{N} 2-\mathrm{C} 2=175.7(2)^{\circ}$ ).

a)

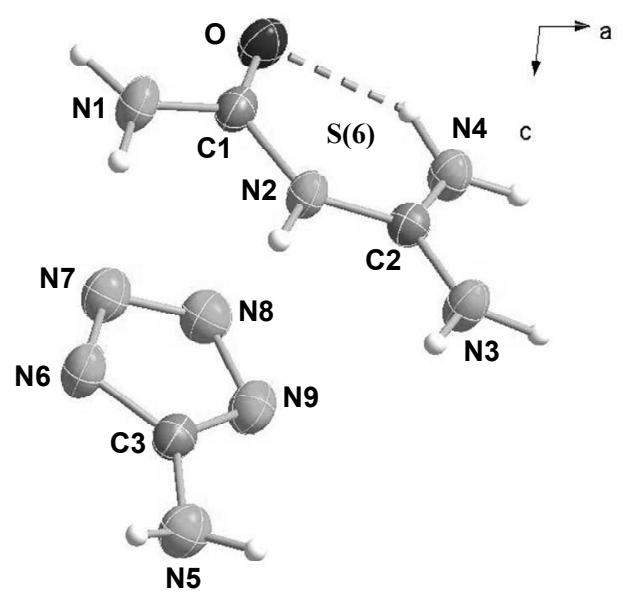

b)

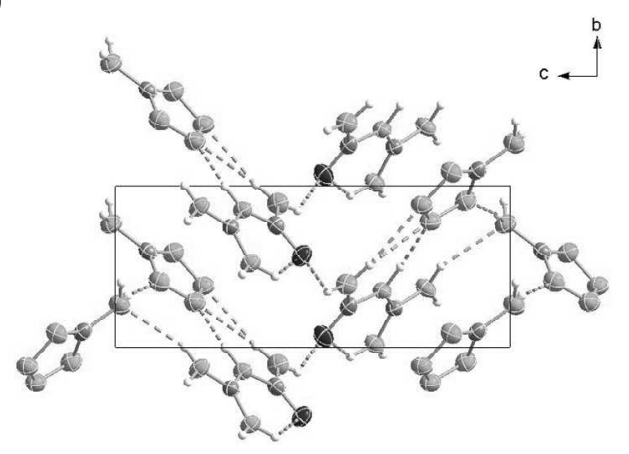

Figure 7. a) Asymmetric unit of $\mathbf{1 0}$ with the labelling scheme and b) view along the $a$-axis showing the formation of hydrogen bonds (dotted lines) in the unit cell. Selected bond distances $(\AA)$ and angles $\left({ }^{\circ}\right)$ for the $\left[\mathrm{N}_{4} \mathrm{C}-\mathrm{NH}_{2}\right]^{-}$anion: $\mathrm{C} 3-\mathrm{N} 5=1.380(2), \mathrm{C} 3-\mathrm{N} 6=$ $1.326(2), \mathrm{N} 6-\mathrm{N} 7=1.356(2), \mathrm{N} 7-\mathrm{N} 8=1.300(2), \mathrm{N} 8-\mathrm{N} 9=$ 1.351(2), N9-C3 = 1.328(2) $\AA$; N5-C3-N6 = 124.0(2), C3-N6-N7 $=104.7(1), \mathrm{N} 6-\mathrm{N} 7-\mathrm{N} 8=108.7(1), \mathrm{N} 7-\mathrm{N} 8-\mathrm{N} 9=110.2(1), \mathrm{N} 8$ N9-C3 $=104.0(1)$, N9-C3-N5 $=123.5(2)$, N9-C3-N6 $=112.2(2)^{\circ}$.

There exists however extensive hydrogen-bonding in the structure (Table S2). The hydrogen-bonding around one of the $\mathrm{GU}^{+}$cations is represented in Figure 8. Every cation is surrounded by other cations and anions so that every hydrogen atoms is involved in the formation of hydrogen bridges. Using graph-set analysis, the primary hydrogen-bonding network is described by dimmeric D1,1(2) and chain C1,1(4) motifs, as well as the usual S(6) graphset $(\mathrm{N} 4 \cdots \mathrm{O}=2.703(2) \AA)$. The secondary level network is formed by several D3,3(X) $(X=7,9,10,11,15)$ finite chain, $\mathbf{C 2 , 2 ( X )}(\mathrm{X}$ $=6-11$ ) infinite chain and (more interestingly) by R2,1(3), R1,2(6) and $\mathbf{R 2 , 2}(X)(X=6,7)$ ring patterns. Some of the ring graph-sets are also represented in Figure 8. For example, N1 forms two weak hydrogen bonds to the same anion $\left(\mathrm{N} 1 \cdots \mathrm{N}^{\mathrm{vi}}=3.293(3) \AA\right.$ and $\mathrm{N} 1 \cdots \mathrm{N}^{\mathrm{vi}}=3.236(3) \AA$; symmetry code: (vi) $\mathrm{x}, 1+\mathrm{y}, \mathrm{z}$ ) describing an R2,1(3) graph-set, whereas the interaction between N1 and N2 with $\mathrm{N} 8{ }^{\mathrm{vi}}$ yields a $\mathbf{R} \mathbf{1 , 2 ( 6 )}$ pattern and the combination of both results in the formation of a larger $\mathbf{R 2 , 2 ( 7 )}$ network.

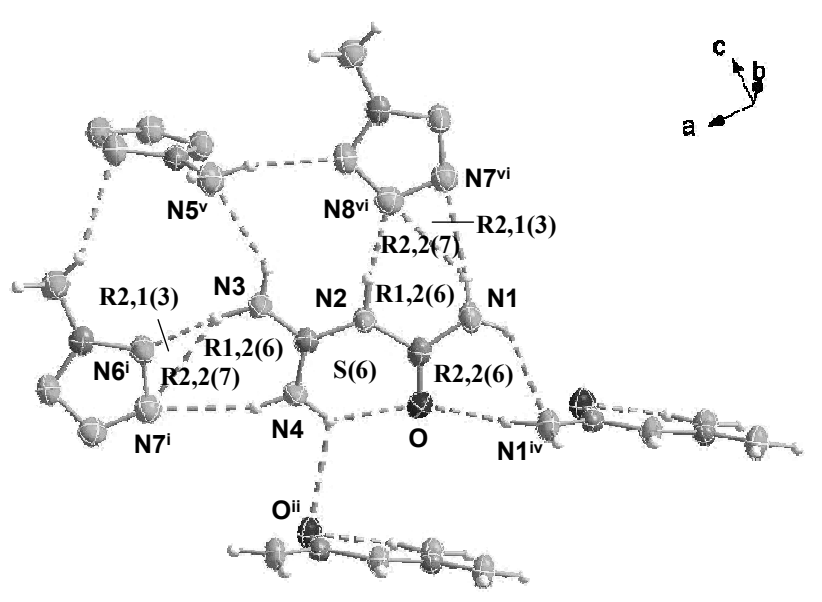

Figure 8. Hydrogen-bonding around the $\mathrm{GU}^{+}$cation in the crystal structure of $\mathbf{1 0}$ showing the formation of some characteristic graphsets.

\section{Thermal and Energetic Properties}

Computational Methods. Electronic energies for all anions and the guanylurea cation were calculated using Møller-Plesset perturbation theory truncated at the second order (MP2) ${ }^{[21]}$ and were used unscaled. The results of the MP2 electronic energy calculations are tabulated in the supporting information (Table S7). As for the vibrational frecuencies calculations (see above) the correlation consistent polarized double-zeta basis set cc-pVDZ was also used. ${ }^{[23,24]}$

The physical and chemical properties of all compounds in this study (6-12) have been collected in Table 3 . As proved by DSC measurements, all compounds have high thermal stabilities as suggested by their high decomposition points ranging from $180{ }^{\circ} \mathrm{C}$ (8a and 8b) to $253{ }^{\circ} \mathrm{C}$ (11). All salts show sharp decomposition without melting (two sharp decomposition steps in the case of the 5,5'-azoatetrazolate salts $\mathbf{1 2 a}$ and $\mathbf{1 2 b}$ ), with the only exception of the 5-aminotetrazolate salt (10), which has a high melting point at $152{ }^{\circ} \mathrm{C}$ and an even higher decomposition temperature at $240{ }^{\circ} \mathrm{C}$, making for a relatively large liquid range $\left(\sim 90^{\circ} \mathrm{C}\right)$. The loss of the water of crystallization in the hydrated salts $8 \mathbf{a}$ and $\mathbf{1 2 a}$ is indicated by an endothermic peak at $\sim 100{ }^{\circ} \mathrm{C}$ in the case of $\mathbf{8 a}$, whereas this is not observable from the DSC curve of compound 12a. Unfortunately, the high insolubility of 12a in all solvents tried did not allow to obtain measurable single crystals of the compound. We assume that the solvent water remains in the structure until decomposition, which would account for the difference in the decomposition temperatures between the two 5,5'-azotetrazolate salts 12a $\left(213{ }^{\circ} \mathrm{C}\right)$ and $\mathbf{1 2 b}\left(199{ }^{\circ} \mathrm{C}\right)$. Lastly, the trend in the decomposition points of $6-12(11>10>12 a>9>6 \sim 7>12 b>$ $\mathbf{8 a}=\mathbf{8 b})$ is in keeping with other studies with salts containing comparable anions. ${ }^{[1 \mathrm{~b}, 11 \mathrm{~b}, 25 \mathrm{~d}, 25 \mathrm{e}, 38]}$

The nitrogen contents and particularly, the combined nitrogen plus oxygen percentages of salts 6-12 are relatively high and vary between $67.3 \%$ (7) and $81.2 \%(6)$, suggesting the possibility to form large amounts of environmentally benign or less malign gaseous products (i.e., $\mathrm{N}_{2}$ and $\mathrm{CO}_{2}$ ). On the other hand, the oxygen contents $(\Omega)$ vary over a large range. The perchlorate salt (7), for which $\Omega=-15.8 \%$, has a value slightly less negative than that of commonly used cyclotrimethylenetrinitramine (RDX, $\Omega=-22 \%$ ), whereas that of the 5 -aminotetrazolate salt $(\mathbf{1 0}, \Omega=-81.2 \%)$ is slightly more negative than that of 1,3,5-trinitrotoluene (TNT, $\Omega=$ $-74 \%$ ). Since density of new energetic materials is a crucial parameter in determining their performance (see discussion below), the densities of all compounds were either measured experimentally using a picnometer $(6,8 b, 9,11,12 a$ and $12 b)$ or 
calculated using X-ray diffraction techniques $(7,8 \mathbf{8}$ and 10$)$. The density values range between moderate $\left(\rho(\mathbf{8 a})=1.494 \mathrm{~g} \mathrm{~cm}^{-3}\right)$ and high $\left(\rho(7)=1.873 \mathrm{~g} \mathrm{~cm}^{-3}\right)$ and are in the range between those of recently reported energetic salts with the $5,5^{\prime}$ '-azotetrazolate anion $\left(\rho \sim 1.5 \mathrm{~g} \mathrm{~cm}^{-3}\right)^{[1 \mathrm{~b}, 1 \mathrm{bb}]}$ and that of the high explosive octogen $\left(\mathrm{HMX}, \rho=1.905 \mathrm{~g} \mathrm{~cm}^{-3}\right)$. $^{[39]}$

For each salt (6-12) the constant volume energy of combustion was predicted on the basis of calculated electronic energies (see "Computational Methods" section above) and an estimation of lattice enthalpy ${ }^{[40]}$ using similar methods to those reported in the literature. ${ }^{[41]}$ The predicted thermochemical properties are also summarized in Table 3. Apart from salts 6 and 11, which have negative energies of formation, the remainder of the compounds, either formed by the highly oxidant perchlorate anion (7) or by highly endothermic moieties, i.e., azide $(\mathbf{8 a}$ and $\mathbf{8 b})$ or tetrazolate $(9,10,12 \mathrm{a}$ and 12b) anions, have positive heats of formation. In particular, the $5,5^{\prime}$-azotetrazolate salts $\mathbf{1 2 a}$ and $\mathbf{1 2 b}$ possess highly positive calculated values $\left(\Delta U_{\mathrm{f}}^{\circ} \sim 2300 \mathrm{~kJ} \mathrm{~kg}^{-1}\right)$, comparable to the high explosive 1-azido-2-nitro-2-azapropane (ANAP, $\Delta U_{\mathrm{f}}^{\circ}=2381$ $\mathrm{kJ} \mathrm{kg}^{-1}$ ). From the energies of formation (back-calculated from MP2 method predicted combustion data), the densities (from picnometer or X-ray measurements) and the molecular formulas of compounds 6-12, the performance of all materials, typically measured by their detonation parameters, i.e., detonation pressure $(P)$ and detonation velocity $(D)$ and their specific impulse $\left(I_{\mathrm{sp}}\right)$, was predicted using the EXPLO5 computer program (see supporting information). ${ }^{[42]}$ The results of the calculations have been collected in Table 4 together with some initial safety testing results of importance and the corresponding values for FOX-12 (guanylurea dinitramide) for comparison purposes. Once again, the change in the anion is reflected in the performance values. Nitrate salt $\mathbf{6}$, which has the most negative heat of formation of all materials in this study, shows accordingly low detonation parameters $(P=17.4$ $\mathrm{GPa}, D=7004 \mathrm{~m} \mathrm{~s}^{-1}$ ), which are nevertheless similar to those of commonly used TNT $\left(P=19.4 \mathrm{GPa}, D=7073 \mathrm{~m} \mathrm{~s}^{-1}\right.$ at a density of $1.60 \mathrm{~g} \mathrm{~cm}^{-3}$ ). The trend in the increase of the detonation parameters is in agreement with the density and heats of formation, which are the two parameters of which performance is most dependant upon. ${ }^{[39,43]}$ Compounds 12a $\left(P=24.3 \mathrm{GPa}, D=8222 \mathrm{~m} \mathrm{~s}^{-1}\right)$ and 12b $\left(P=23.3 \mathrm{GPa}, D=8115 \mathrm{~m} \mathrm{~s}^{-1}\right)$, which have the highest (positive) heats of formation, have also the largest detonation parameters, comparable to FOX-12 $\left(P=27.6 \mathrm{GPa}, D=8308 \mathrm{~m} \mathrm{~s}^{-}\right.$ $\left.{ }^{1}\right)$, which has been developed as a "high performance insensitive ammunition" ${ }^{[13,14]}$ All compounds are also higher performing than recently developed policyano compounds regardless of the higher positive heats of formation of the latter ${ }^{[44]}$ Although relatively low, the specific impulses computed for compounds 6-12 are higher than those expected for policyano-based molecules ${ }^{[44]}$ and the 5,5'azotetrazolate salts $\mathbf{1 2 a}$ and $\mathbf{1 2 b}$ exhibit values perfectly comparable to that of FOX-12 $\left(I_{\mathrm{sp}}=210 \mathrm{~s}\right)$. Sensitivity testing using standard BAM tests ${ }^{[45]}$ revealed marked insensitivity for all compounds, which are neither impact $(>40 \mathrm{~J})$ nor friction sensitive $(>360 \mathrm{~N})$, which is a clear advantage in terms of safety in comparison with new tetrazolium-based energetic materials with comparable anions ${ }^{[\mathrm{lh}, 1 \mathrm{lc}]}$ or commonly used RDX (impact $=7 \mathrm{~J}$, friction $=120 \mathrm{~N}) .^{[39]}$ In addition, all 6-12 are insensitive to an electrostatic discharge of $\sim 20 \mathrm{kV}$. Lastly, the perchlorate (7) and the azide (8a and $\mathbf{8 b})$ salts deflagrate when put into sudden contact with the flame of a Bunsen burner ("flame test"), similar to the dinitramide salt (FOX-12), whereas the remainder of the salts burn nicely giving little or no smoke.

The detonation parameters for formulations of the guanylurea salts 6-12 with an oxidant such as ammonium nitrate (AN) or ammonium dinitramide (ADN) were also calculated using the EXPLO 5 code and are tabulated in the supporting information (Tables S8 and S9). The formulations calculated were composed of compound and oxidant in oxygen neutral ratios. Mixtures of 6-12 with AN (Table S8) generally show an increase in the detonation parameters in respect to the stand-alone compounds and in compounds to values not significantly different from those predicted for TNT formulations with AN $(P=25.4 \mathrm{GPa}, D=8086$ $\mathrm{m} \mathrm{s}^{-1}$ ), whereas mixtures with ADN (Table S9) have a much better predicted performance, again reaching valuable comparable to mixtures of TNT and ADN $\left(P=31.7 \mathrm{GPa}, D=8739 \mathrm{~m} \mathrm{~s}^{-1}\right)$. In all cases, the performances predicted for formulations of 6-12 with $\mathrm{AN}$ or ADN, are higher than those of AN $(P=15.1 \mathrm{GPa}, D=6602$ $\left.\mathrm{m} \mathrm{s}^{-1}\right)$ or $\operatorname{ADN}\left(P=22.7 \mathrm{GPa}, D=7650 \mathrm{~m} \mathrm{~s}^{-1}\right)$ alone.

Table 3 Physical and chemical properties of guanylurea salts 6-12.

\begin{tabular}{|c|c|c|c|c|c|c|c|c|c|}
\hline & 6 & 7 & $8 \mathbf{8 a}$ & $8 \mathbf{b}$ & 9 & 10 & 11 & $12 a$ & $12 b$ \\
\hline Formula & $\mathrm{C}_{2} \mathrm{H}_{7} \mathrm{~N}_{5} \mathrm{O}_{4}$ & $\mathrm{C}_{2} \mathrm{H}_{7} \mathrm{~N}_{4} \mathrm{O}_{5} \mathrm{Cl}$ & $\mathrm{C}_{2} \mathrm{H}_{9} \mathrm{~N}_{7} \mathrm{O}_{2}$ & $\mathrm{C}_{2} \mathrm{H}_{7} \mathrm{~N}_{7} \mathrm{O}$ & $\mathrm{C}_{3} \mathrm{H}_{7} \mathrm{~N}_{9} \mathrm{O}_{3}$ & $\mathrm{C}_{3} \mathrm{H}_{9} \mathrm{~N}_{9} \mathrm{O}$ & $\mathrm{C}_{8} \mathrm{H}_{9} \mathrm{~N}_{7} \mathrm{O}_{8}$ & $\mathrm{C}_{6} \mathrm{H}_{15} \mathrm{~N}_{18} \mathrm{O}_{2.5}$ & $\mathrm{C}_{6} \mathrm{H}_{14} \mathrm{~N}_{18} \mathrm{O}_{2}$ \\
\hline $\begin{array}{c}\text { Mol. Mass }\left(\mathrm{g} \mathrm{mol}^{-}\right. \\
\left.{ }^{-}\right)\end{array}$ & 165.05 & 202.01 & 163.08 & 145.07 & 217.07 & 187.09 & 331.05 & 379.16 & 370.15 \\
\hline$T_{\mathrm{m}}\left({ }^{\circ} \mathrm{C}\right)^{a}$ & & & & & & 152 & & & \\
\hline$T_{\mathrm{d}}\left({ }^{\circ} \mathrm{C}\right)^{b}$ & 203 & 204 & 180 & 180 & 209 & 240 & 253 & 213 & 199 \\
\hline$N(\%)^{c}$ & 42.4 & 27.7 & 60.1 & 67.6 & 58.1 & 67.4 & 29.6 & 66.5 & 68.1 \\
\hline$N+O(\%)^{d}$ & 81.2 & 67.3 & 79.7 & 78.6 & 80.1 & 75.9 & 68.3 & 77.0 & 76.7 \\
\hline$\Omega(\%)^{e}$ & -33.9 & -15.8 & -63.8 & -71.7 & -47.9 & -81.2 & -60.4 & -71.7 & -73.5 \\
\hline$\rho\left(\mathrm{g} \mathrm{cm}^{3}\right)^{f}$ & $1.567 *$ & 1.873 & 1.494 & $1.499 *$ & $1.615^{*}$ & 1.577 & $1.669 *$ & $1.599 *$ & $1.588^{*}$ \\
\hline$-\Delta U_{\text {comb. }} /$ cal g $^{-1 g}$ & 1987 & 1851 & 3078 & 2995 & 2442 & 3273 & 2928 & 3354 & 3343 \\
\hline$\Delta U_{\mathrm{f}}^{\circ} / \mathrm{kJ} \mathrm{kg}^{-1 h}$ & -2392 & +88 & +303 & +341 & +282 & +623 & -1046 & +2267 & +2322 \\
\hline$\Delta H_{\mathrm{f}}^{\circ} / \mathrm{kJ} \mathrm{kg}^{-1 i}$ & -2512 & -4 & +190 & +213 & +174 & +497 & -1136 & +2157 & +2208 \\
\hline
\end{tabular}

${ }^{a, b}$ Melting $\left(T_{\mathrm{m}}\right)$ and decomposition $\left(T_{\mathrm{d}}\right)$ points from DSC measurements carried out at a heating rate of $\beta=5{ }^{\circ} \mathrm{C} \min ^{-1}$. ${ }^{c} \mathrm{Nitrogen}$ contents. ${ }^{d}$ Combined nitrogen and oxygen contents. ${ }^{e}$ Oxygen balance,,${ }^{f}$ Calculated density from X-ray measurements or experimentally determined from picnometer experiments $(*) .{ }^{g}$ Constant volume energy of combustion. ${ }^{h}$ Energy of formation. ${ }^{i}$ Heat of formation. ${ }^{g, h, i}$ Values predicted based on electronic energies and using the MP2 method.

Table 4 Predicted detonation and combustion parameters (using the EXPLO5 code) and sensitivity data for guanylurea salts 6-12.

\begin{tabular}{|c|c|c|c|c|c|c|c|c|c|}
\hline & $\begin{array}{r}T_{\mathrm{ex}} \\
(\mathrm{K})^{a} \\
\end{array}$ & $\begin{array}{c}V_{0} \\
\left(\mathrm{~L} \mathrm{~kg}^{-1}\right)^{b}\end{array}$ & $\begin{array}{c}P \\
(\mathrm{GPa})^{c}\end{array}$ & $\begin{array}{c}D \\
\left(\mathrm{~m} \mathrm{~s}^{-1}\right)^{d}\end{array}$ & $\operatorname{Impact}_{(\mathrm{J})^{e}}$ & $\begin{array}{l}\text { Friction } \\
(\mathrm{N})^{e}\end{array}$ & $\begin{array}{l}\text { ESD } \\
(+/-)^{f}\end{array}$ & Thermal Shock $^{g}$ & $\begin{array}{l}I_{\mathrm{sp}} \\
(\mathrm{s})^{h}\end{array}$ \\
\hline 6 & 2624 & 858 & 17.4 & 7004 & $>40$ & $>360$ & - & Burns & 177 \\
\hline 7 & & & & & $>40$ & $>360$ & - & Deflagrates & \\
\hline $\mathbf{8 a}$ & 2642 & 917 & 20.6 & 7880 & $>40$ & $>360$ & - & Deflagrates & 170 \\
\hline $8 b$ & 2129 & 875 & 16.9 & 7289 & $>40$ & $>360$ & - & Deflagrates & 165 \\
\hline 9 & 2944 & 801 & 20.3 & 7439 & $>40$ & $>360$ & - & Burns & 183 \\
\hline 10 & 2085 & 854 & 18.4 & 7530 & $>40$ & $>360$ & - & Burns & 165 \\
\hline 11 & 3158 & 688 & 19.7 & 7152 & $>40$ & $>360$ & - & Burns & 161 \\
\hline $12 \mathrm{a}$ & 3034 & 816 & 24.3 & 8222 & $>40$ & $>360$ & - & Burns & 210 \\
\hline
\end{tabular}




\section{Long-term stability and decomposition gases}

Due to the interesting energetic properties of the 5,5'-azotetrazolate salt 12a, i.e., high decomposition temperature, high nitrogen content, low sensitivity and relatively high performance, the longterm stability of the compound was assessed using a Systag FlexyTSC instrument (thermal safety calorimetry) ${ }^{[46]}$ in combination with a RADEX V5 oven and the SysGraph software. A $\sim 0.5 \mathrm{~g}$ of finely divided and homogeneous sample of the material was loaded in a glass test-vessel at atmospheric pressure. The substance was then tempered at $\sim 50{ }^{\circ} \mathrm{C}$ below its decomposition point (from the DSC measurements) for 48 hours. Figure 9 shows the thermal safety calorimetry (TSC) curve of 12a. At a temperature of $\sim 160{ }^{\circ} \mathrm{C}$, the TSC curve of the salt looks identical to that of the oven and visual inspection of the sample shows no apparent change in color or decomposition. This result can be extrapolated to a shelf live of above 15 years at room temperature, which is attractive when thinking about a possible application.

Table 4. ICT-code predicted heats of explosion $\left(\Delta H_{\mathrm{ex}}, \mathrm{cal} \mathrm{g}^{-1}\right)$ and decomposition gases $\left(\mathrm{g} \mathrm{kg}^{-1}\right)$ for guanylurea salts $\mathbf{6}-\mathbf{1 2}$.

\begin{tabular}{rrrrrrrrrrr}
\hline Compound & $\mathrm{CO}_{2}$ & $\mathrm{H}_{2} \mathrm{O}$ & $\mathrm{N}_{2}$ & $\mathrm{CO}$ & $\mathrm{H}_{2}$ & $\mathrm{NH}_{3}$ & $\mathrm{CH}_{4}$ & $\mathrm{HCN}$ & $\mathrm{C}$ & $\Delta H_{\mathrm{ex}}$ \\
\hline $\mathbf{6}$ & 102.7 & 341.6 & 407.4 & 16.2 & 0.6 & 20.0 & 1.1 & 0.5 & 109.3 & 927 \\
$\mathbf{7}$ & 217.1 & 255.7 & 271.8 & 17.0 & 0.2 & 5.6 & $180.0^{a}$ & 0.3 & 51.7 & 1549 \\
$\mathbf{8 a}$ & 3.2 & 216.2 & 481.8 & 3.0 & 2.4 & 144.2 & 13.5 & 1.1 & 134.4 & 966 \\
$\mathbf{8 b}$ & 1.1 & 122.0 & 547.2 & 1.8 & 2.6 & 155.4 & 18.9 & 1.1 & 149.8 & 625 \\
$\mathbf{9}$ & 27.7 & 220.7 & 551.0 & 8.3 & 0.9 & 35.4 & 2.4 & 0.7 & 152.6 & 958 \\
$\mathbf{1 0}$ & 0.6 & 94.9 & 534.7 & 1.3 & 2.7 & 168.1 & 21.0 & 1.1 & 175.5 & 604 \\
$\mathbf{1 1}$ & 228.6 & 227.4 & 290.6 & 31.5 & 0.5 & 6.4 & 1.0 & 0.3 & 213.2 & 1104 \\
$\mathbf{1 2 a}$ & 1.5 & 116.2 & 564.1 & 2.0 & 2.0 & 121.6 & 12.8 & 1.0 & 178.7 & 1042 \\
$\mathbf{1 2 b}$ & 1.1 & 95.2 & 580.0 & 1.7 & 2.1 & 122.0 & 14.5 & 1.0 & 182.3 & 977 \\
\hline
\end{tabular}

${ }^{a} \mathrm{No} \mathrm{CH}_{4}$ and instead $\mathrm{HCl}$ was predicted for the perchlorate salt (7).

The ICT code predicts the formation of large amounts of environmentally friendly molecular nitrogen $\left(\sim 270-580 \mathrm{~g} \mathrm{~kg}^{-1}\right)$, which is the main decomposition product for all compounds and, in particular, for the nitrogen-richest 5,5'-azotetrazolate salts (12a and 12b). After this, $\mathrm{H}_{2} \mathrm{O}, \mathrm{NH}_{3}$ and $\mathrm{C}$ (soot) are, in general, expected to be formed in largest amounts. In particular, in the case of the better oxygen balanced salts 6, 7 and $\mathbf{1 1}$ the amount of carbon atoms, which can be potentially oxidized to $\mathrm{CO}_{2}\left(>100 \mathrm{~g} \mathrm{~kg}^{-1}\right)$ is markedly larger than for the remainder of the salts. In addition, highly toxic gases such as $\mathrm{HCN}$ or $\mathrm{CO}$ are only foreseen to form in small amounts. On the other hand, the only slightly negative oxygen balance of perchlorate salt $7(\Omega=-15.8 \%)$, accounts for the small amounts of C (soot) calculated, however, relatively large amounts of $\mathrm{HCl}$ gas are computed. In any case, compound 7 exhibits the highest calculated density of all compounds in this work $(\rho=1.873$ $\mathrm{g} \mathrm{cm}^{3}$ ), which correlates well with its highest heat of explosion $\left(\Delta H_{\mathrm{ex}}=1549 \mathrm{cal} \mathrm{g}^{-1}\right)$, perfectly comparable to that of $1,3,5-$ trinitroperhydro-1,3,5-triazine (RDX, $\Delta H_{\mathrm{ex}}=1593 \mathrm{cal} \mathrm{g}^{-1}$ ), whereas, with the exception of salts $\mathbf{8 b}$ and 10, high heats of explosions above $900 \mathrm{cal} \mathrm{g}^{-1}$ are expected for the rest of the materials discussed in this work.

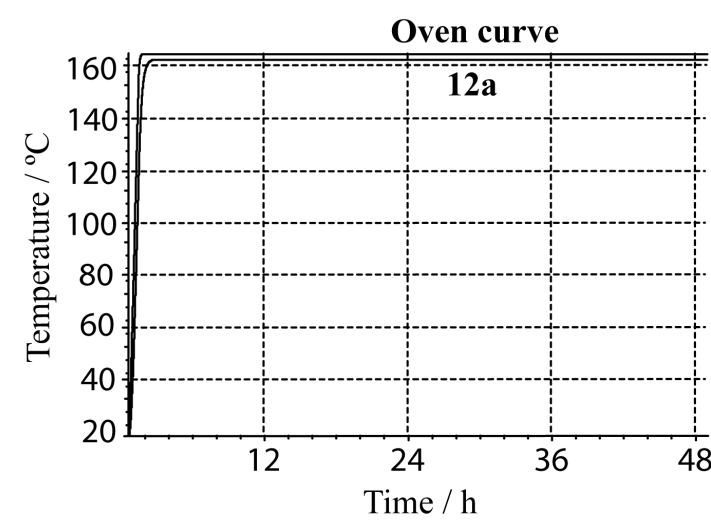

Figure 9. Thermal safety calorimetry plot of 5,5'-azotetrazolate salt 12a.

Using the densities of compounds 6-12 (either calculated from Xray or observed from picnometer measurements), their molecular formulas and the calculated heats of formation, the ICT code $\mathrm{e}^{[47]}$ was used to predict the heats of explosion and the decomposition gases of the guanylurea salts in this work. The predicted values have been collected in Table 5 .

Burns 206

Deflagrates 210

${ }^{a}$ Temperature of the explosion gases; ${ }^{b}$ Volume of the explosion gases; ${ }^{c}$ Detonation pressure; ${ }^{d}$ Detonation velocity; ${ }^{e}$ Impact and friction 作 coil V-24); ${ }^{g}$ Response to fast heating in the "flame test"; ${ }^{h}$ Specific impulse; ${ }^{i}$ The values for FOX-12 (guanylurea dinitramide) have been calculated using the EXPLO5 code ${ }^{[42]}$ from its energy of formation, calculated from its heat of formation $\left(\Delta H_{\mathrm{f}}^{\circ}=-355 \mathrm{~kJ} \mathrm{~mol}^{-1}\right){ }^{[13]}$ 
predicted to decompose giving large amounts of environmentally friendly molecular nitrogen (ICT code). Lastly, the 5,5'azotetrazolate salt 12a also shows great long-term thermal stability (TSC) in addition to good thermal stability (DSC), high nitrogen content, low sensitivity and a relatively high performance, suggesting its potential for application

\section{Experimental Section}

Caution! Tetrazoles and nitrogen-rich materials are highly endothermic compounds and tend to explode under certain conditions. The synthesis and handling of the salts reported here should only be carried out by expert personnel. In particular, silver azide is a highly explosive solid and should never be dried nor used in large quantities. The use of safety equipment such as Kevlar gloves, leather coat, face shield and ear plugs is recommended and large scale synthesis is discouraged for all compounds.

\section{General. See supporting information.}

Guanylurea Chloride (4): Cyanoguanidine (6.089 g, 72.0 mmol) was dissolved in $50 \mathrm{~mL}$ water in a $250 \mathrm{~mL}$ round bottom flask and $37 \%$ concentrated hydrochloric acid $(30 \mathrm{~mL}, 364.0$ $\mathrm{mmol}$ ) was added slowly be means of a dropping funnel. The reaction mixture was then heated to boiling and left to react for 15 min. at this temperature and the solvent and excess $\mathrm{HCl}$ were removed by storing the solution in an oven at $80^{\circ} \mathrm{C}$ for 2 days. The white solid left behind was pure by elemental analysis and the yield is approximately quantitative $(9.838 \mathrm{~g})$. Single crystals suitable for $\mathrm{X}$-ray analysis were obtained when a diluted solution of the chloride salt 4 in water was left to slowly evaporate. $\mathrm{C}_{2} \mathrm{H}_{7} \mathrm{~N}_{4} \mathrm{OCl}$ (138.03 $\left.\mathrm{g} \mathrm{mol}^{-1}\right)$ calcd.: C 17.39, H 5.11, N 40.58\%; found: $\mathrm{C}$ 17.07, H 5.01, N 40.42\%; DSC $\left(5{ }^{\circ} \mathrm{C} \min ^{-1},{ }^{\circ} \mathrm{C}\right): 168$ (m.p. + dec); IR $\left(\mathrm{KBr}, \mathrm{cm}^{-1}\right) \tilde{v}=3410(\mathrm{vw}) 3378(\mathrm{vw}) 3251(\mathrm{vw}) 3143(\mathrm{~m})$ 2989(vw) 1693(vs) 1622(s) 1571(m) 1535(m) 1462(w) 1339(m) 1129(w) 1075(w) 931(vw) 742(m) 718(w) 692(m) 649(s) 606(s) 584(s) 579(s) 561(s); Raman $\left(400 \mathrm{~mW}, 25^{\circ} \mathrm{C}, \mathrm{cm}^{-1}\right) \widetilde{v}=3191$ (9) 1726(21) 1624(14) 1588(7) 1466(11) 1345(4) 1136(18) 1086(24) 1007(9) 940(29) 758(8) 694(18) 565(16) 504(6) 456(25) 437(37) 270(11) 175(15) 140(14); ${ }^{1} \mathrm{H}$ NMR (DMSO- $d_{6}, 25^{\circ} \mathrm{C}$ ) $\delta / \mathrm{ppm}: 10.4$ $(\mathrm{s}, 1 \mathrm{H}, \mathrm{NH}), 8.2\left(\mathrm{~s}, 4 \mathrm{H}, \mathrm{NH}_{2}\right), 7.2\left(\mathrm{~s}, 2 \mathrm{H}, \mathrm{NH}_{2}\right) ;{ }^{13} \mathrm{C}$ NMR (DMSO$\left.d_{6}, 25{ }^{\circ} \mathrm{C}\right) \delta / \mathrm{ppm}$ : $155.6(1 \mathrm{C}, \mathrm{C} 1 / \mathrm{C} 2), 154.5(1 \mathrm{C}, \mathrm{C} 2 / \mathrm{C} 1) ; \mathrm{m} / \mathrm{z}$ $\left(\mathrm{FAB}^{+}\right.$, xenon, $6 \mathrm{keV}$, glycerine matrix): $103.1\left(59,\left[\mathrm{C}_{2} \mathrm{H}_{7} \mathrm{~N}_{4} \mathrm{O}\right]^{-}\right)$, $205.1\left(4, \quad\left\{\left[\mathrm{C}_{2} \mathrm{H}_{7} \mathrm{~N}_{4} \mathrm{O}\right]_{2}^{+}-\mathrm{H}^{+}\right\}\right), 241.1\left(13,\left\{\left[\mathrm{C}_{2} \mathrm{H}_{7} \mathrm{~N}_{4} \mathrm{OCl}\right]\right.\right.$ $\left.\left.\left[\mathrm{C}_{2} \mathrm{H}_{7} \mathrm{~N}_{4} \mathrm{O}\right]^{+}\right\}\right)$.

Guanylurea Nitrate (6): 6 was synthesized as described in ref. ${ }^{[19]}$ in a $97 \%$ yield. The elemental analysis and NMR data are in agreement with those previously reported. $\mathrm{C}_{2} \mathrm{H}_{7} \mathrm{~N}_{5} \mathrm{O}_{4}(165.05 \mathrm{~g}$ mol $^{-1}$ ) calcd.: C 14.54, H 4.27, N 42.42\%; found: C 14.48, H 4.17, $\mathrm{N} 42.21 \%$; ${ }^{1} \mathrm{H}$ NMR (DMSO- $d_{6}, 25^{\circ} \mathrm{C}$ ) $\delta / \mathrm{ppm}$ : $9.51(\mathrm{~s}, 1 \mathrm{H}, \mathrm{NH})$, $8.13\left(\mathrm{~s}, 4 \mathrm{H}, \mathrm{NH}_{2}\right), 7.14\left(\mathrm{~s}, 2 \mathrm{H}, \mathrm{NH}_{2}\right) ;{ }^{13} \mathrm{C} \mathrm{NMR}\left(\mathrm{DMSO}-d_{6}, 25^{\circ} \mathrm{C}\right.$ )

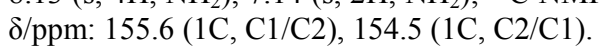

Guanylurea Perchlorate (7): 7 was synthesized as reported previously ${ }^{[19]}$ in a $91 \%$ yield. Both elemental analysis and NMR data agree with the published data. $\mathrm{C}_{2} \mathrm{H}_{7} \mathrm{~N}_{4} \mathrm{O}_{5} \mathrm{Cl}\left(202.01 \mathrm{~g} \mathrm{~mol}^{-1}\right)$ calcd.: C 11.88, H 3.49, N 27.73\%; found: C 11.72, H 3.45, N 27.591\%; ${ }^{1} \mathrm{H}$ NMR (DMSO- $\left.d_{6}, 25^{\circ} \mathrm{C}\right) \delta / \mathrm{ppm}$ : $9.61(\mathrm{~s}, 1 \mathrm{H}, \mathrm{NH})$, $8.02\left(\mathrm{~s}, 4 \mathrm{H}, \mathrm{NH}_{2}\right), 7.04\left(\mathrm{~s}, 2 \mathrm{H}, \mathrm{NH}_{2}\right) ;{ }^{13} \mathrm{C} \mathrm{NMR}$ (DMSO- $d_{6}, 25^{\circ} \mathrm{C}$ )



Guanylurea Azide Monohydrate (8a). The reaction was conducted parallely four times in the following manner: in a plastic beaker (!!) sodium azide $(0.325 \mathrm{~g}, 5.0 \mathrm{mmol})$ was dissolved in 6 $\mathrm{mL}$ water and reacted with a solution of silver nitrate $(0.850 \mathrm{~g}, 5.0$ $\mathrm{mmol}$ ) in $6 \mathrm{~mL}$ water causing immediate precipitation of highly sensitive silver azide. The suspension was stirred for $15 \mathrm{~min}$, filtered through gravity and the insoluble solid was washed with water to rinse any traces of unreacted sodium azide or silver nitrate. Meanwhile, $4(0.650 \mathrm{~g}, 4.71 \mathrm{mmol})$ was dissolved in $10 \mathrm{~mL}$ water in a plastic beaker (!!) and the silver azide was carefully rinsed into the reaction flask with water. The reaction mixture was stirred for $2 \mathrm{~h}$., heated shortly to boiling and the insoluble silver chloride and excess silver azide were filtered hot yielding a slightly yellow solution. The four filtrates were combined and rotavaporated until a white solid started to precipitate. At this point, the insoluble solid was dissolved by shortly heating to boiling and the solution left to slowly cool down yielding crystals of the azide salt as the monohydrate species $(2.292 \mathrm{~g}, 75 \%)$. X-ray quality crystals of the monohydrated species $\mathbf{8 a}$, were obtained by slow evaporation of an aqueous solution of the compound. $\mathrm{C}_{2} \mathrm{H}_{9} \mathrm{~N}_{7} \mathrm{O}_{2}\left(163.14 \mathrm{~g} \mathrm{~mol}^{-1}\right)$ calcd.: $\mathrm{C} 14.72, \mathrm{H} 5.56, \mathrm{~N} 60.11 \%$; found: C 14.58, H 5.51, N 59.72\%; DSC $\left(5{ }^{\circ} \mathrm{C} \mathrm{min}{ }^{-1},{ }^{\circ} \mathrm{C}\right): \sim 100(-$ $\left.\mathrm{H}_{2} \mathrm{O}\right), \sim 180$ (m.p. $\left.+\mathrm{dec}\right)$; IR $\left(\mathrm{KBr}, \mathrm{cm}^{-1}\right) \widetilde{v}=3342(\mathrm{vs}) 3168(\mathrm{vs})$ 2343(vw) 2114(m) 2042(vs) 1727(vs) 1698(s) 1671(s) 1645(vs)

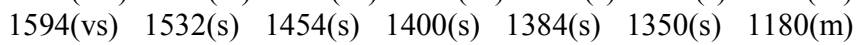
$1131(\mathrm{~m}) \quad 1107(\mathrm{~m}) \quad 1087(\mathrm{~m}) \quad 1050(\mathrm{~m}) \quad 928(\mathrm{w}) \quad 802(\mathrm{w}) \quad 730(\mathrm{~m})$ 703(m) 640(s) 627(s) 558(m) 490(m); Raman $\left(400 \mathrm{~mW}, 25{ }^{\circ} \mathrm{C}\right.$, $\left.\mathrm{cm}^{-1}\right) \tilde{v}=3172(4) \quad 1728(58) \quad 1582(65) \quad 1338(100) \quad 1256(73)$ $\begin{array}{lllllll}1134(74) & 1054(83) & 932(63) & 812(55) & 708(55) & 563(33) & 447(43)\end{array}$ $300(23) 181(43) 89(5) ;{ }^{1} \mathrm{H}$ NMR (DMSO- $\left.d_{6}, 25^{\circ} \mathrm{C}\right) \delta / \mathrm{ppm}$ : $9.72(\mathrm{~s}$, $1 \mathrm{H}, \mathrm{NH}), 8.33\left(\mathrm{~s}, 4 \mathrm{H}, \mathrm{NH}_{2}\right), 7.14\left(\mathrm{~s}, 2 \mathrm{H}, \mathrm{NH}_{2}\right), 3.7\left(\mathrm{~s}, 2 \mathrm{H}, \mathrm{H}_{2} \mathrm{O}\right)$; ${ }^{13} \mathrm{C}$ NMR (DMSO- $\left.d_{6}, 25{ }^{\circ} \mathrm{C}\right) \delta / \mathrm{ppm}: 155.7$ (1C, C1/C2), 154.5 $(1 \mathrm{C}, \mathrm{C} 2 / \mathrm{C} 1) ;{ }^{14} \mathrm{~N}$ NMR (DMSO- $\left.d_{6}, 25{ }^{\circ} \mathrm{C}\right) \delta / \mathrm{ppm}:-137\left(1 \mathrm{~N}, v_{1 / 2}=\right.$ $100 \mathrm{~Hz}, \mathrm{~N} N \mathrm{~N}),-271\left(2 \mathrm{~N}, v_{1 / 2}=290 \mathrm{~Hz}, N \mathrm{~N} N\right) ; m / z\left(\mathrm{FAB}^{+}\right.$, xenon, $6 \mathrm{keV}$, glycerine matrix): $19.1\left(4, \mathrm{H}_{3} \mathrm{O}^{+}\right), 103.1\left(100,\left[\mathrm{C}_{2} \mathrm{H}_{7} \mathrm{~N}_{4} \mathrm{O}\right]^{+}\right)$, $205.2\left(30,\left\{\left[\mathrm{C}_{2} \mathrm{H}_{7} \mathrm{~N}_{4} \mathrm{O}\right]^{+}{ }_{2}-\mathrm{H}^{+}\right\}\right), 256.1\left(15,\left[\mathrm{C}_{2} \mathrm{H}_{7} \mathrm{~N}_{4} \mathrm{O}-\text { matrix }\right]^{+}\right)$.

Guanylurea Azide (8b): The anhydrous compound was synthesized in quantitative yield by dehydration of 8a $(0.214 \mathrm{~g}$, $1.31 \mathrm{mmol})$ at $60^{\circ} \mathrm{C}$ under high vacuum $\left(10^{-3} \mathrm{mbar}\right)$ over 2 days. $\mathrm{C}_{2} \mathrm{H}_{7} \mathrm{~N}_{7} \mathrm{O}\left(145.12 \mathrm{~g} \mathrm{~mol}^{-1}\right)$ calcd.: $\mathrm{C} 16.55, \mathrm{H} 4.86, \mathrm{~N} 67.56 \%$; found: C 16.35, H 5.01, N 67.42\%; DSC $\left(5{ }^{\circ} \mathrm{C} \mathrm{min}^{-1},{ }^{\circ} \mathrm{C}\right): \sim 180$ (m.p. + dec); IR $\left(\mathrm{KBr}, \mathrm{cm}^{-1}\right) \widetilde{v}=3212(\mathrm{~s})$ 3172(s) 2117(m) 2040(s) $1725(\mathrm{vs}) \quad 1696(\mathrm{~s}) \quad 1670(\mathrm{~s}) \quad 1645(\mathrm{vs}) \quad 1598(\mathrm{~s}) \quad 1531(\mathrm{~m})$ 1455(s) $1397(\mathrm{~s}) \quad 1385(\mathrm{~m}) \quad 1357(\mathrm{~s}) \quad 1170(\mathrm{~m}) \quad 1112(\mathrm{~m}) \quad 1089(\mathrm{~m})$ 1054(m) 876(w) 730(m) 699(m) 625(s) 564(w) 498(w); Raman $\left(400 \mathrm{~mW}, 25^{\circ} \mathrm{C}, \mathrm{cm}^{-1}\right) \widetilde{v}=3092(3) 1723(43) 1585(57) 1337(100)$ $\begin{array}{lllllll}1259(68) & 1137(81) & 1057(89) & 936(54) & 818(42) & 714(37) & 607(2)\end{array}$ 566(21) 452(37) 308(26) 254(3) 180(42) 91(3); ${ }^{1} \mathrm{H}$ NMR (DMSO$\left.d_{6}, 25^{\circ} \mathrm{C}\right) \delta / \mathrm{ppm}$ : $9.82(\mathrm{~s}, 1 \mathrm{H}, \mathrm{NH}), 8.25\left(\mathrm{~s}, 4 \mathrm{H}, \mathrm{NH}_{2}\right), 7.22(\mathrm{~s}, 2 \mathrm{H}$, $\mathrm{NH}_{2}$ ); ${ }^{13} \mathrm{C}$ NMR (DMSO- $d_{6}, 25{ }^{\circ} \mathrm{C}$ ) $\delta / \mathrm{ppm}: 155.5(1 \mathrm{C}, \mathrm{C} 1 / \mathrm{C} 2)$, $154.3(1 \mathrm{C}, \mathrm{C} 2 / \mathrm{C} 1) ;{ }^{14} \mathrm{~N}$ NMR (DMSO- $\left.d_{6}, 25{ }^{\circ} \mathrm{C}\right) \delta / \mathrm{ppm}:-135(1 \mathrm{~N}$, $\left.v_{1 / 2}=90 \mathrm{~Hz}, \mathrm{~N} N \mathrm{~N}\right),-274\left(2 \mathrm{~N}, v_{1 / 2}=275 \mathrm{~Hz}, N \mathrm{~N} N\right) ; m / z\left(\mathrm{FAB}^{+}\right.$, xenon, $6 \mathrm{keV}$, glycerine matrix): $103.1\left(100,\left[\mathrm{C}_{2} \mathrm{H}_{7} \mathrm{~N}_{4} \mathrm{O}\right]^{+}\right), 205.2$ $\left(24,\left\{\left[\mathrm{C}_{2} \mathrm{H}_{7} \mathrm{~N}_{4} \mathrm{O}\right]^{+}{ }_{2}-\mathrm{H}^{+}\right\}\right), 256.1\left(19,\left[\mathrm{C}_{2} \mathrm{H}_{7} \mathrm{~N}_{4} \mathrm{O} \text {-matrix }\right]^{+}\right)$.

Guanylurea 5-Nitrotetrazolate (9): Anhydrous ammonium 5nitrotetrazolate $(1.028 \mathrm{~g}, 7.7 \mathrm{mmol})$ was dissolved in $20 \mathrm{~mL}$ water and reacted with barium hydroxide octahydrate $(1.228 \mathrm{~g}, 3.89$ $\mathrm{mmol}$ ). The initially insoluble material dissolved upon heating and the reaction mixture was refluxed for 3 hours (evolution of ammonia gas). Solid guanylurea sulphate monohydrate $(1.213 \mathrm{~g}$, $3.89 \mathrm{mmol}$ ) was added portion-wise to the hot solution causing immediate precipitation of barium sulphate. After 30 minutes reflux time the insoluble solid was filtered through a plug of celite (previously washed with water) and the celite was washed with a small volume of hot water. The filtrate was transferred into a crystallization shell and the solvent left to slowly evaporate yielding a cream colored powder. No further purification was necessary $(1.581 \mathrm{~g}, 94 \%) . \mathrm{C}_{3} \mathrm{H}_{7} \mathrm{~N}_{9} \mathrm{O}_{3}\left(217.15 \mathrm{~g} \mathrm{~mol}^{-1}\right)$ calcd.: $\mathrm{C}$ 16.59, H 3.25, N 58.05\%; found: C 16.44, H 3.18, N 57.51\%; DSC $\left(5{ }^{\circ} \mathrm{C} \mathrm{min}{ }^{-1},{ }^{\circ} \mathrm{C}\right): 209$ (m.p. $\left.+\mathrm{dec}\right) ; \mathrm{IR}\left(\mathrm{KBr}, \mathrm{cm}^{-1}\right) \tilde{v}=3461(\mathrm{vs})$ 3417(s) 3368(s) 3213(s) 2993(m) 2453(w) 2170(w) 2054(w)

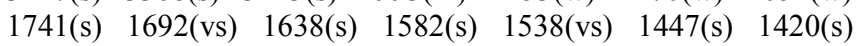
$1319(\mathrm{~s}) \quad 1177(\mathrm{~m}) \quad 1120(\mathrm{~m}) \quad 1077(\mathrm{~m}) \quad 1060(\mathrm{~m}) \quad 1032(\mathrm{~m}) \quad 1022(\mathrm{~m})$ 915(w) 845(m) 775(w) 765(w) 723(w) 695(m) 671(m) 558(w) 
490(w) 453(w); Raman (400 mW, $25{ }^{\circ} \mathrm{C}, \mathrm{cm}^{-1}$ ) $\widetilde{v}=3238(1)$ 1731(3) 1691(1) 1590(2) 1541(4) 1446(9) 1422(100) 1321(4) 1171(3) $1120(2) \quad 1064(23) \quad 1045(19) \quad 1032(25) \quad 1025(21) \quad 920(2)$ 845(8) 771(2) 704(3) 547(3) 435(9) 261(3) 242(4) 151(3); ${ }^{1} \mathrm{H}$ NMR (DMSO- $\left.d_{6}, 25^{\circ} \mathrm{C}\right) \delta / \mathrm{ppm}: 9.51(\mathrm{~s}, 1 \mathrm{H}, \mathrm{NH}), 8.21(\mathrm{~s}, 4 \mathrm{H}$, $\mathrm{NH}_{2}$ ), 7.07 (s, $\left.2 \mathrm{H}, \mathrm{NH}_{2}\right) ;{ }^{13} \mathrm{C}$ NMR (DMSO- $\left.d_{6}, 25{ }^{\circ} \mathrm{C}\right) \delta / \mathrm{ppm}$ : $168.8\left(1 \mathrm{C}, \mathrm{C}_{\text {ring }}\right), 155.6(1 \mathrm{C}, \mathrm{C} 1 / \mathrm{C} 2), 154.7(1 \mathrm{C}, \mathrm{C} 2 / \mathrm{C} 1) ;{ }^{14} \mathrm{~N}$ NMR $\left(\right.$ DMSO $\left.-d_{6}, 25^{\circ} \mathrm{C}\right) \delta / \mathrm{ppm}:+25\left(2 \mathrm{~N}, v_{1 / 2}=500 \mathrm{~Hz}, \mathrm{~N} 2 / 3\right),-23(1 \mathrm{~N}$, $\left.v_{1 / 2}=80 \mathrm{~Hz}, \mathrm{NO}_{2}\right),-60\left(2 \mathrm{~N}, v_{1 / 2}=415 \mathrm{~Hz}, \mathrm{~N} 1 / 4\right) ; \mathrm{m} / z\left(\mathrm{FAB}^{-}\right.$, xenon, $6 \mathrm{keV}, \mathrm{m}-\mathrm{NBA}$ matrix) $114.0\left(100,\left[\mathrm{~N}_{4} \mathrm{C}-\mathrm{NO}_{2}\right]^{-}\right) ; \mathrm{m} / z\left(\mathrm{FAB}^{+}\right.$, xenon, $6 \mathrm{keV}$, glycerine matrix): $103.1\left(100,\left[\mathrm{C}_{2} \mathrm{H}_{7} \mathrm{~N}_{4} \mathrm{O}\right]^{+}\right), 205.2$ (12, $\left.\left\{\left[\mathrm{C}_{2} \mathrm{H}_{7} \mathrm{~N}_{4} \mathrm{O}\right]^{+}{ }_{2}-\mathrm{H}^{+}\right\}\right), 256.1\left(30,\left[\mathrm{C}_{2} \mathrm{H}_{7} \mathrm{~N}_{4} \mathrm{O} \text {-matrix }\right]^{+}\right)$.

Guanylurea 5-Aminotetrazolate (10): 5-Amino $1 H$-tetrazole $(1.018 \mathrm{~g}, 11.61 \mathrm{mmol})$ and barium hydroxide octahydrate $(1.831 \mathrm{~g}$, $5.80 \mathrm{mmol}$ ) were suspended in $25 \mathrm{~mL}$ water. The reaction mixture was refluxed for two hours forming a clear solution and reacted with guanylurea sulphate monohydrate $(1.809 \mathrm{~g}, 5.80 \mathrm{mmol})$ causing the precipitation of barium sulphate. After $15 \mathrm{~min}$. reflux time the solid was filtered through celite and the filtrate rotavaporated to dryness yielding the crude product, which could be recrystallized from water/ethanol $(1.815 \mathrm{~g}, 83 \%)$. Slow evaporation of a saturated solution of the compound in methanol rendered X-ray quality single crystals. $\mathrm{C}_{3} \mathrm{H}_{9} \mathrm{~N}_{9} \mathrm{O}\left(187.16 \mathrm{~g} \mathrm{~mol}^{-1}\right)$ calcd.: C 19.25, H 4.85, N 67.35\%; found: C 19.09, H 4.92, N $67.01 \%$; DSC $\left(5^{\circ} \mathrm{C} \mathrm{min}^{-1},{ }^{\circ} \mathrm{C}\right)$ : 152 (m.p.) 240 (dec); IR (KBr, $\left.\mathrm{cm}^{-1}\right) \tilde{v}=3455(\mathrm{~s}) \quad 3415(\mathrm{~s}) \quad 3363(\mathrm{~s}) \quad 3291(\mathrm{~s}) \quad 3193(\mathrm{~m}) \quad 2894(\mathrm{~m})$ $2700(\mathrm{~m}) \quad 2165(\mathrm{w}) \quad 1736(\mathrm{~s}) \quad 1701(\mathrm{vs}) \quad 1603(\mathrm{~s}) \quad 1522(\mathrm{~s}) \quad 1481(\mathrm{~m})$ 1442(m) 1431(m) 1331(m) 1222(m) 1154(w) 1109(m) 1070(m) 1018(w) 924(w) 887(w) 825(w) 774(m) 754(m) 699(m) 581(m) 566(m) 485(m); Raman $\left(400 \mathrm{~mW}, 25{ }^{\circ} \mathrm{C}, \mathrm{cm}^{-1}\right) \widetilde{v}=3164$ (2) 1714(5) $1595(8)$ 1523(15) $1433(7)$ 1351(5) $1224(20) \quad 1126(9)$ 1074(34) 1018(5) 926(13) 745(13) 697(13) 574(6) 445(25) 421(11) 348(7) 264(8) 205(7) 182(8) 100(2) 83(1); ${ }^{1} \mathrm{H}$ NMR (DMSO- $d_{6}$, $\left.25^{\circ} \mathrm{C}\right) \delta / \mathrm{ppm}: 9.87(\mathrm{~s}, 1 \mathrm{H}, \mathrm{NH}), 8.33\left(\mathrm{~s}, 4 \mathrm{H}, \mathrm{NH}_{2}\right), 7.47(\mathrm{~s}, 2 \mathrm{H}$, $\left.\mathrm{NH}_{2}\right), 6.17$ (s, $\left.2 \mathrm{H}, \mathrm{NH}_{2(\mathrm{At})}\right) ;{ }^{13} \mathrm{C}$ NMR (DMSO- $\left.d_{6}, 25^{\circ} \mathrm{C}\right) \delta / \mathrm{ppm}$ : 157.6 (1C, $\mathrm{C}_{\text {ring }}$ ), 155.6 (1C, C1/C2), $154.4(1 \mathrm{C}, \mathrm{C} 2 / \mathrm{C} 1) ; \mathrm{m} / \mathrm{z}$ $\left(\mathrm{FAB}^{-}\right.$, xenon, $6 \mathrm{keV}, \mathrm{m}-\mathrm{NBA}$ matrix) $84.1\left(35,\left[\mathrm{~N}_{4} \mathrm{C}-\mathrm{NH}_{2}\right]^{-}\right)$, 237.1 (33, $\left.\left[\mathrm{N}_{4} \mathrm{C}-\mathrm{NH}_{2} \text {-matrix }\right]^{-}\right) 390.2\left(15,\left[\mathrm{~N}_{4} \mathrm{C}-\mathrm{NH}_{2} \text {-matrix }\right]^{-}\right)$; $\mathrm{m} / \mathrm{z}$ ( $\mathrm{FAB}^{+}$, xenon, $6 \mathrm{keV}$, glycerine matrix): 103.1 (88, $\left.\left[\mathrm{C}_{2} \mathrm{H}_{7} \mathrm{~N}_{4} \mathrm{O}\right]^{+}\right), \quad 205.2\left(6, \quad\left\{\left[\mathrm{C}_{2} \mathrm{H}_{7} \mathrm{~N}_{4} \mathrm{O}\right]^{+}{ }_{2}-\mathrm{H}^{+}\right\}\right), \quad 256.1 \quad(19$, $\left[\mathrm{C}_{2} \mathrm{H}_{7} \mathrm{~N}_{4} \mathrm{O} \text {-matrix }\right]^{+}$).

Guanylurea Picrate (11): 4 (1.150 g, $8.3 \mathrm{mmol})$ was dissolved in $50 \mathrm{~mL}$ water in a $100 \mathrm{~mL}$ round bottom flask. Neat picric acid $(1.900 \mathrm{~g}, 8.3 \mathrm{mmol})$ was added portionwise at room temperature causing precipitation of a yellow precipitate. The reaction mixture was brought ro reflux and reacted for 1.5 hours at this temperature. After cooling the solid was filtered and left to air-dry yielding pure $11(2.261 \mathrm{~g}, 82 \%) . \mathrm{C}_{8} \mathrm{H}_{9} \mathrm{~N}_{7} \mathrm{O}_{8}\left(331.05 \mathrm{~g} \mathrm{~mol}^{-1}\right)$ calcd.: $\mathrm{C} 29.00, \mathrm{H}$ 2.74, N 29.60\%; found: C 29.01, H 2.66, N 29.46\%; DSC $\left(5{ }^{\circ} \mathrm{C}\right.$ $\left.\min ^{-1},{ }^{\circ} \mathrm{C}\right): 253$ (m.p. $\left.+\mathrm{dec}\right)$; IR $\left(\mathrm{KBr}, \mathrm{cm}^{-1}\right) \widetilde{v}=3434(\mathrm{vw})$ 3397(w) 3376(w) 3167(w) 1726(m) 1693(m) 1651(w) 1608(m) 1592(m) 1563(m) 1547(m) 1510(m) 1486(m) 1446(w) 1430(m) 1363(m) 1353(m) 1320(s) 1267(s) 1164(m) 1132(m) 1080(s) 943(w) 919(m) 840(vw) 822(vw) 785(m) 743(m) 711(s) 704(s) 612(vs) 567(s); Raman $\left(400 \mathrm{~mW}, 25{ }^{\circ} \mathrm{C}, \mathrm{cm}^{-1}\right) \widetilde{v}=1612(9)$ $\begin{array}{llllll}1567(19) & 1550(27) & 1491(13) & 1430(8) & 1367(44) & 1343(90)\end{array}$ 1316(100) 1302(83) 1275(46) 1167(20) 1135(9) 1084(20) 945(21) 925(16) 826(61) 790(10) 714(15) 543(11) 461(18) 426(12) 367(12) 339(21) 292(12) 194(10); ${ }^{1} \mathrm{H}$ NMR (DMSO- $d_{6}, 25^{\circ} \mathrm{C}$ ) $\delta / \mathrm{ppm}: 9.56$ $(\mathrm{s}, 1 \mathrm{H}, \mathrm{NH}), 8.57(\mathrm{~s}, 2 \mathrm{H}, \mathrm{Ar}-\mathrm{H}), 7.99\left(\mathrm{~s}, 4 \mathrm{H}, \mathrm{NH}_{2}\right), 7.14(\mathrm{~s}, 2 \mathrm{H}$, $\left.\mathrm{NH}_{2}\right) ;{ }^{13} \mathrm{C}$ NMR (DMSO- $\left.d_{6}, 25^{\circ} \mathrm{C}\right) \delta / \mathrm{ppm}: 160.8\left(2 \mathrm{C}, \mathrm{C}-\mathrm{NO}_{2}\right)$, $155.4\left(1 \mathrm{C}, \mathrm{C}_{1} / \mathrm{C}_{2}\right), 154.4\left(1 \mathrm{C}, \mathrm{C}_{2} / \mathrm{C}_{1}\right), 141.8(1 \mathrm{C}, \mathrm{CO}), 125.2(2 \mathrm{C}$, $\mathrm{CH}), 124.3\left(1 \mathrm{C}, \mathrm{C}-\mathrm{NO}_{2}\right) ;{ }^{14} \mathrm{~N}$ NMR (DMSO- $\left.d_{6}, 25^{\circ} \mathrm{C}\right) \delta / \mathrm{ppm}:-12$ (3 N, $\left.v_{1 / 2}=300 \mathrm{~Hz}, \mathrm{NO}_{2}\right) ; \mathrm{m} / \mathrm{z}\left(\mathrm{FAB}^{-}\right.$, xenon, $6 \mathrm{keV}$, glycerine matrix): $227.9\left(8,\left[\mathrm{C}_{6} \mathrm{H}_{2} \mathrm{~N}_{3} \mathrm{O}_{7}\right]^{-}\right), m / z\left(\mathrm{FAB}^{+}\right.$, xenon, $6 \mathrm{keV}$, glycerine matrix): $103.1\left(14,\left[\mathrm{C}_{2} \mathrm{H}_{7} \mathrm{~N}_{4} \mathrm{O}\right]^{+}\right), 205.1\left(1,\left\{\left[\mathrm{C}_{2} \mathrm{H}_{7} \mathrm{~N}_{4} \mathrm{O}\right]^{+}{ }_{2}\right.\right.$ $\left.\left.-\mathrm{H}^{+}\right\}\right), 241.1\left(3,\left\{\left[\mathrm{C}_{2} \mathrm{H}_{7} \mathrm{~N}_{4} \mathrm{OCl}\right] \cdot\left[\mathrm{C}_{2} \mathrm{H}_{7} \mathrm{~N}_{4} \mathrm{O}\right]^{+}\right\}\right)$.

Guanylurea 5,5'-Azotetrazolate Hemihydrate (12a): Sodium $5,5^{\prime}$-azotetrazolate pentahydrate $(2.502 \mathrm{~g}, 8.34 \mathrm{mmol})$ was dissolved in $25 \mathrm{~mL}$ boiling water and reacted with a solution of guanylurea chloride $(2.420 \mathrm{~g}, 16.68 \mathrm{mmol})$ in $25 \mathrm{~mL}$ boiling water. A yellow solid precipitated and the reaction mixture was refluxed for 1 hour and left to cool slowly. The yellow highly insoluble powder was filtered, washed with water and left to air-dry $(2.575 \mathrm{~g}$, $81 \%$ ). Elemental analysis showed the presence of half a molecule of water and repeated recrystallization from water did not vary this result. $\mathrm{C}_{6} \mathrm{H}_{15} \mathrm{~N}_{18} \mathrm{O}_{2.5}\left(379.12 \mathrm{~g} \mathrm{~mol}^{-1}\right)$ calcd.: $\mathrm{C} 19.00, \mathrm{H} \mathrm{3.99, \textrm {N }}$ 66.46\%; found: C 18.98, H 3.95, N 66.28\%; DSC $\left(5^{\circ} \mathrm{C} \mathrm{min}^{-1},{ }^{\circ} \mathrm{C}\right)$ : 213 (dec), 240 (dec); IR (KBr, cm $\left.{ }^{-1}\right) \widetilde{v}=3450(\mathrm{~s}) 3400(\mathrm{vs})$ 3318(vs) 3203(vs) 2798(s) 2215(w) 1720(vs) 1641(vs) 1595(vs) $1529(\mathrm{~m}) \quad 1467(\mathrm{~m}) \quad 1448(\mathrm{~m}) \quad 1397(\mathrm{~s}) \quad 1356(\mathrm{~s}) \quad 1195(\mathrm{~m}) \quad 1176(\mathrm{~m})$ 1160(m) $1135(\mathrm{~m}) \quad 1088(\mathrm{~m}) \quad 1080(\mathrm{~m}) \quad 1030(\mathrm{~m}) \quad 930(\mathrm{w}) \quad 841(\mathrm{~m})$ 794(w) 770(m) 737(s) 702(m) 614(s) 571(m) 556(s) 446(m) 428(w); Raman (400 mW, $\left.25^{\circ} \mathrm{C}, \mathrm{cm}^{-1}\right) \widetilde{v}=1480(42) 1420(32)$ 1379(100) 1309(3) 1193(4) 1093(10) 1076(6) 1054(41) 1033(16) 976(6) 923(8) 448(6) 377(4) 168(4); ${ }^{1} \mathrm{H}$ NMR (DMSO- $d_{6}, 25^{\circ} \mathrm{C}$ )

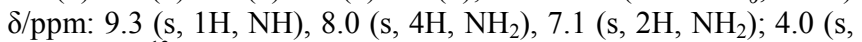
$1 \mathrm{H}, \mathrm{H}_{2} \mathrm{O}$ ); ${ }^{13} \mathrm{C}$ NMR (DMSO- $\left.d_{6}, 25{ }^{\circ} \mathrm{C}\right) \delta / \mathrm{ppm}: 173.0\left(2 \mathrm{C}, \mathrm{C}_{\text {ring }}\right.$ ), $155.7(1 \mathrm{C}, \mathrm{C} 1 / \mathrm{C} 2), 154.5(1 \mathrm{C}, \mathrm{C} 2 / \mathrm{C} 1) ; \mathrm{m} / z$ ( $\mathrm{FAB}^{-}$, xenon, $6 \mathrm{keV}$, glycerine matrix): $168.0\left(100,\left[\mathrm{C}_{2} \mathrm{HN}_{10}\right]^{-}\right), 331.0\left(5,\left[\mathrm{C}_{2} \mathrm{H}_{2} \mathrm{~N}_{10}\right.\right.$ $\left.\left.\mathrm{C}_{2} \mathrm{HN}_{10}\right]^{-}\right) ; m / z\left(\mathrm{FAB}^{+}\right.$, xenon, $6 \mathrm{keV}$, glycerine matrix): 103.0 (10, $\left.\left[\mathrm{C}_{6} \mathrm{H}_{2} \mathrm{~N}_{3} \mathrm{O}_{7}\right]^{-}\right), 205.0\left(4,\left\{\left[\mathrm{C}_{2} \mathrm{H}_{7} \mathrm{~N}_{4} \mathrm{O}\right]^{+}{ }_{2}-\mathrm{H}^{+}\right\}\right)$.

Guanylurea 5,5'-Azotetrazolate (12b): Method 1. Sodium 5,5'azotetrazolate pentahydrate $(0.951 \mathrm{~g}, 3.17 \mathrm{mmol})$ was dissolved in $10 \mathrm{~mL}$ hot water $\left(\sim 70{ }^{\circ} \mathrm{C}\right)$ and reacted with a solution of guanylurea chloride $(0.920 \mathrm{~g}, 6.34 \mathrm{mmol})$ in $10 \mathrm{~mL}$ hot water. Immediate precipitation of a yellow solid was observed and the reaction mixture was shortly heated to reflux. After this time, the insoluble solid was filtered hot, washed with cold water, acetone and dried under vacuum $(1.003 \mathrm{~g}, 85 \%)$. No further purification was necessary.

Method 2. Alternatively, the hemihydrate compound (12a) could be dehydrated quantitatively by heating at $70{ }^{\circ} \mathrm{C}$ for 2 days. $\mathrm{C}_{6} \mathrm{H}_{14} \mathrm{~N}_{18} \mathrm{O}_{2}$ (370.15 $\mathrm{g} \mathrm{mol}^{-1}$ ) calcd.: $\mathrm{C}$ 19.45, H 3.81, N 68.09\%; found: $\mathrm{C} 19.39, \mathrm{H} 3.91, \mathrm{~N} 67.19 \%$; $\operatorname{DSC}\left(5^{\circ} \mathrm{C} \min ^{-1},{ }^{\circ} \mathrm{C}\right): 199$ (dec), 240 (dec); IR (KBr, cm $\left.{ }^{-1}\right) \widetilde{v}=3446(\mathrm{vw}) 3397(\mathrm{w}) 3313(\mathrm{~m})$ 3194(m) 2789(w) 2213(vw) 1718(vs) 1684(s) 1639(s) 1586(s) 1528(w) 1465(w) 1445(w) 1396(s) 1353(s) 1194(m) $1128(\mathrm{~m})$ 1088(m) 1040(w) 1026(s) 930(w) 832(s) 768(s) 738(s) 701(s); Raman $\left(400 \mathrm{~mW}, 25^{\circ} \mathrm{C}, \mathrm{cm}^{-1}\right) \widetilde{v}=1481(43) 1420(31) 1379(100)$ 1192(4) 1093(11) 1054(38) 1032(15) 921(8) 703(2) 451(4) 162(2); ${ }^{1} \mathrm{H}$ NMR (DMSO- $\left.d_{6}, 25^{\circ} \mathrm{C}\right) \delta / \mathrm{ppm}: 9.4(\mathrm{~s}, 1 \mathrm{H}, \mathrm{NH}), 8.1(\mathrm{~s}, 4 \mathrm{H}$, $\mathrm{NH}_{2}$ ), 7.1 (s, $\left.2 \mathrm{H}, \mathrm{NH}_{2}\right) ;{ }^{13} \mathrm{C}$ NMR (DMSO- $\left.d_{6}, 25^{\circ} \mathrm{C}\right) \delta / \mathrm{ppm}: 172.7$ $\left(2 \mathrm{C}, \mathrm{C}_{\text {ring }}\right), 155.9(1 \mathrm{C}, \mathrm{C} 1 / \mathrm{C} 2), 155.4(1 \mathrm{C}, \mathrm{C} 2 / \mathrm{C} 1) ; \mathrm{m} / \mathrm{z}\left(\mathrm{FAB}^{-}\right.$, xenon, $6 \mathrm{keV}$, glycerine matrix): $168.0\left(100,\left[\mathrm{C}_{2} \mathrm{HN}_{10}\right]^{-}\right), 331.0(7$, $\left.\left[\mathrm{C}_{2} \mathrm{H}_{2} \mathrm{~N}_{10} \cdot \mathrm{C}_{2} \mathrm{HN}_{10}\right]^{-}\right) ; \mathrm{m} / z\left(\mathrm{FAB}^{+}\right.$, xenon, $6 \mathrm{keV}$, glycerine matrix): $103.0\left(8,\left[\mathrm{C}_{6} \mathrm{H}_{2} \mathrm{~N}_{3} \mathrm{O}_{7}\right]^{-}\right), 205.0\left(2,\left\{\left[\mathrm{C}_{2} \mathrm{H}_{7} \mathrm{~N}_{4} \mathrm{O}\right]^{+}{ }_{2}-\mathrm{H}^{+}\right\}\right)$.

\section{Acknowledgements}

Financial support of this work by the Ludwig-Maximilian University of Munich (LMU), the Fonds der Chemischen Industrie (FCI), the European Research Office (ERO) of the U.S. Army Research Laboratory (ARL) and ARDEC (Armament Research, Development and Engineering Center) under contract nos. N 62558-05-C-0027, R\&D 1284-CH-01, R\&D 1285CH-01, 9939-AN-01 \& W911NF-07-1-0569 and the Bundeswehr Research Institute for Materials, Explosives, Fuels and Lubricants (WIWEB) under contract nos. E/E210/4D004/X5143 \& E/E210/7D002/4F088 is gratefully acknowledged. The authors acknowledge collaborations Dr. M. Krupka (OZM Research, Czech Republic) in the development of new testing and evaluation methods for energetic materials and with Dr. M. Sucesca (Brodarski Institute, Croatia) in the development of new computational 
codes to predict the detonation parameters of high-nitrogen explosives. We are indebted to and thank Dr. Betsy M. Rice (ARL, Aberdeen, Proving Ground, MD) for many helpful and inspired discussions and support of our work.

[1] a) S. Radhakrishnan, M. B. Talawar, S. Venugopalan, V. L. Narasimhan, J. Hazard. Mater. 2008, 152(3), 1317-1324; b) T. M. Klapötke, C. Miró Sabaté, Chem. Mater. 2008, 20(5), 1750-1763; c) M. Göbel, T. M. Klapötke, Acta Crystallogr. 2008, C64(2), o58-o60; d) T. M. Klapötke, J. Stierstorfer, Helvet. Chim. Acta 2007, 90(11), 2132-2150; e) S. Xu, S. Yang, C. Hanneng, 2006, 14(5), 377-380; f) T. M. Klapötke, C. Miró Sabaté, Z. Anorg. Allg. Chem. 2007, 633, 2671-2677; g) C. Darwich, K. Karagiosoff, T. M. Klapötke, C. Miró Sabaté, Z. Anorg. Allg. Chem. 2008, 634, 61-68; h) K. Karaghiosoff, T. M. Klapötke, P. Mayer, C. Miró Sabaté, A. Penger, J. M. Welch, Inorg. Chem. 2008, 47, 1007 1019 ; i) T. M. Klapötke, C. Miró Sabaté, M. Rusan, Z. Anorg. Allg. Chem. 2008, 634(4), 688-695; j) T. M. Klapötke, C. Miró Sabaté, J. M. Welch, Z. Anorg. Allg. Chem. 2008, 634(5), 857-866.

[2] a) Z. Zeng, H. Gao, B. Twamley, J. M. Shreeve, J. Mater. Chem. 2007, 17, 3819-3826; b) H. Xue, H. Gao, B. Twamley, J. M. Shreeve, Chem. Mater. 2007, 19, 1731-1739; c) H. Gao, C. Ye, O. D. Gupta, J. C. Xiao, M. A. Hiskey, B. Twamley, J. M. Shreeve, Chem. Eur. J. 2007, 13, 3853-3860; d) Y. Gao, B. Twamley, J. M. Shreeve, Chem. Eur. J. 2006, 12, 9010-9018

[3] a) R. P. Singh, R. D. Verma, D. T. Meshri, J. M. Shreeve, Angew. Chem. Int. Ed. 2006, 45, 3584-3601; b) H. Xue, B. Twamley, J. M. Shreeve, Eur. J. Inorg. Chem. 2006, 2959-2965; c) H. Gao, R. Wang, B. Twamley, M. A. Hiskey, J. M. Shreeve, Chem. Comm. 2006, 40074009; d) R. Wang, H. Gao, C. Ye, B. Twamley, J. M. Shreeve, Inorg. Chem. 2007, 46, 932-938; e) H. Gao, C. Ye, O. D. Gupta, J. C. Xiao, M. A. Hiskey, B. Twamley, J. M. Shreeve, Chem. Eur J. 2007, 13, 3853-3860; f) Y. Huang, H. Gao, B. Twamley, J. M. Shreeve, Eur. J. Inorg. Chem. 2007, 2025-2030; g) C. Ye, H. Gao, B. Twamley, J. M. Shreeve, New J. Chem. 2008, 32, 317-322; h) H. Gao, Z. Zeng, B. Twamley, J. M. Shreeve, Chem. Eur. J. 2008, 14, 1282-1290.

[4] a) J. Geith, G. Holl, T. M. Klapötke, J. J. Weigand, Combust. Flame 2004, 139(4), 358-366; b) J. Geith, T. M. Klapötke, J. Weigand, G. Holl, Propell. Explos. Pyrotech. 2004, 29, 3-8.

[5] L. A. Deshusses, J. Deshusses, Helvet. Chim. Acta 1933, 16, 783-92

[6] G. H. Foster, D. W. Jayne, US 2,277,823, 1942.

[7] K. Szabo, A. H. Freiberg, US 3,479,437, 1969.

[8] J. J. Hlavka, P. Bitha, Y. I. Lin, US 4,544,759, 1985.

[9] a) W. T. A. Harrison, Sol. Sta. Sci. 2006, 8(3-4), 371-378; b) I. V. Medrish, E. V. Peresypkina, A. V. Virovets, L. B. Serezhkina, Rus. J. Coord. Chem. 2006, 32(12), 910-914; c) P. Bhattacharjee, M. Prasad, P. Kumari, Orient. J. Chem. 1998, 14(2), 259-265.

[10] a) R. K. Ray, G. B. Kauffman, Polyhedron 1994, 13(18), 2591-2598; b) R. K. Ray, M. K. Bandyopadhyay, G. B. Kauffman, Polyhedron 1989, 8(6), 757-762; c) C. R. Saha, S. K. Hota, Ind. J. Chem. 1986, 25A(4), 340-344; d) A. Syamal, P. K. Mandal, S. K. Verma, Trans. Met. Chem. 1978, 3(5), 288-291; e) C. R. Saha, J. Inorg. Nucl. Chem. 1976, 38(9), 1635-1640; f) D. Sen, C. Saha, Dalton Trans. 1976, 9, 776-779.

[11] a) Y. Guo, H. Gao, B. Twamley, J. M. Shreeve, Adv. Mater. 2007, 19(19), 2884-2888; b) A. Hammerl, M. A. Hiskey, G. Holl, T. M. Klapötke, K. Polborn, J. Stierstorfer, J. J. Weigand, Chem. Mater. 2005, 17(14), 3784-3793; c) T. M. Klapötke, P. Mayer, C. Miró Sabaté, J. M. Welch, N. Wiegand, Inorg. Chem. 2008, 47(13), 6014-6027.

[12] a) A. Langlet, WO 9,855,428, 1998; b) N. Latypov, A. Langlet, WO 9,946,202, 1999; c) P. Sjoberg, WO 0,040,523, 2000; d) C. Voerde, H. Skifs, WO 0,070,823, 2005.

[13] H. Östmark, U. Bemm, H. Bergman, A. Langlet, Thermoch. Acta 2002, 384, 253-259.

[14] a) U. Bemm, H. Ostmark, Acta Crystallog. 1998, C54(12), 1997-1999; b) N. V. Latypov, J. Bergman, A. Langlet, U. Wellmar, U. Bemm, Tetrahedron 1998, 54(38), 11525-11536; c) T. M. Klapötke, Moderne Anorganische Chemie, 2nd ed., Walter de Gruyter, Berlin/New York, Germany/USA, 2003; d) J. Evers, T. M. Klapötke, P. Mayer, G. Oehlinger, J. Welch, Inorg. Chem. 2006, 45(13), 4996-5007.

[15] a) H. Xue, J. M. Shreeve, Adv. Mater. 2005, 17(17), 2142; b) H. Xue, B. Twamley, J. M. Shreeve, Inorg. Chem. 2005, 44(20), 7009.

[16] M. Scoponi, E. Polo, V. Bertolasi, V. Carassiti, G. Bertelli, Perkin Trans. 2 1991, 10, 1619-1624.

[17] R. Andreasch, Monat. Chem. 1927, 48, 145-154.

[18] T. Ooshima, S. Kuroda, Y. Nosaka, JP 45,040,898, 1970.

[19] T. M. Klapötke, C. Miró Sabaté, Heteroat. Chem. 2008, 19(3), 301306.

[20] M. J. Frisch, G. W. Trucks, H. B. Schlegel, G. E. Scuseria, M. A. Robb, J. R. Cheeseman, J. A. Montgomery Jr., T. Vreven, K. N. Kudin,
J. C. Burant, J. M. Millam, S. S. Iyengar, J. Tomasi, V. Barone, B. Mennucci, M. Cossi, G. Scalmani, N. Rega, G. A. Petersson, H. Nakatsuji, M. Hada, M. Ehara, K. Toyota, R. Fukuda, J. Hasegawa, M. Ishida, T. Nakajima, Y. Honda, O. Kitao, H. Nakai, M. Klene, X. Li, J. E. Knox, H. P. Hratchian, J. B. Cross, C. Adamo, J. Jaramillo, R. Gomperts, R. E. Stratmann, O. Yazyev, A. J. Austin, R. Cammi, C. Pomelli, J. W. Ochterski, P. Y. Ayala, K. Morokuma, G. A. Voth, P. Salvador, J. J. Dannenberg, V. G. Zakrzewski, S. Dapprich, A. D. Daniels, M. C. Strain, O. Farkas, D. K. Malick, A. D. Rabuck, K. Raghavachari, J. B. Foresman, J. V. Ortiz, Q. Cui, A. G. Baboul, S. Clifford, J. Cioslowski, B. B. Stefanov, G. Liu, A. Liashenko, P. Piskorz, I. Komaromi, R. L. Martin, D. J. Fox, T. Keith, M. A. AlLaham, C. Y. Peng, A. Nanayakkara, M. Challacombe, P. M. W. Gill, B. Johnson, W. Chen, M. W. Wong, C. Gonzalez, J. A. Pople, Gaussian G03W, Gaussian 03, Revision A.1, Gaussian Inc., Pittsburgh PA, 2003.

[21] J. A. Pople, R. Seeger, R. Krishnan, Int. J. Quantum Chem. Symp. 1977, 11, 149-163.

[22] A. P. Scott, L. Radom, J. Phys. Chem. 1996, 100, 16502-16513.

[23] A. K. Rick, T. H. Dunning, J. H. Robert, J. Chem. Phys. 1992, 96, 6796-6806.

[24] A. P. Kirk, E. W. David, T. H. Dunning, J. Chem. Phys. 1994, 100, $7410-7415$.

[25] a) T. M. Klapötke, C. Miró Sabaté, J. Welch, Dalton Trans. 2008, 6372-6380; b) T. M. Klapötke, C. Miró Sabaté, J. Welch, Eur. J. Inorg. Chem. 2009, 769-776; c) T. M. Klapökte, C. Miró Sabaté, Z. Anorg. Allg. Chem. 2009, ASAP; d) T. M. Klapötke, C. Miró Sabaté, Z. Anorg. Allg. Chem. 2008, 634, 1017-1024; e) T. M. Klapötke, C. Miró Sabaté, Eur. J. Inorg. Chem. 2008, 34, 5350-5366; f) N. B. Colthup, L. H. Daly, S. E. Wiberley, Introduction to Infrared and Raman Spectroscopy, Academic Press, Boston, USA, 1990.

[26] CrysAlis CCD, version 1.171.27p5 beta, Oxford Diffraction Ltd..

[27] CrysAlis RED, version 1.171.27p5 beta, Oxford Diffraction Ltd..

[28] a) A. Altomare, G. Cascarano, C. Giacovazzo, A. Guagliardi, J. Appl. Crystallogr. 1993, 26, 343; b) A. Altomare, M. C. Burla, M. Camalli, G. L. Cascarano, C. Giacovazzo, A. Guagliardi, A. G. Moliterni, G. Polidori, R. Spagna, J. Appl. Crystallogr. 1999, 32, 115-119.

[29] G. M. Sheldrick, SHELX-92, Program for Crystal Structure Solution, Institut für Anorganische Chemie der Universität Göttingen, Germany, 1994.

[30] G. M. Sheldrick, SHELX-97, Program for Crystal Structure Solution, Institut für Anorganische Chemie der Universität Göttingen, Germany, 1997.

[31] L. J. Farrugia, J. Appl. Crystallogr. 1999, 32, 837.

[32] A. L. Spek, PLATON, A Multipurpose Crystallographic Tool, Utrecht, The Netherlands, 1999.

[33] CCDC numbers 737952 (4), 665842 (7), 737953 (8a) and 737954 (10) contain the supplementary crystallographic data for this paper. These data can be obtained free of charge from The Cambridge Crystallographic Data Centre via www.ccdc.cam.ac.uk/ data_request/cif.

[34] A. F. Hollemann, E. Wieberg, N. Wieberg, Lehrbuch der Anorganischen Chemie, 101 th ed., Walter de Gruyter, Berlin, 1995.

[35] A. Bondi, J. Phys. Chem. 1964, 68, 441-451.

[36] a) J. Bernstein, R. E. Davis, L. Shimoni, N.-L. Chang, Angew. Chem. Int. Ed. Engl. 1995, 34, 1555-1573; b) W. D. S. Motherwell, G. P. Shields, F. H. Allen, Acta Crystallogr., Sect. B 2000, 56, 466-473; c) W. D. S. Motherwell, G. P. Shields, F. H. Allen, Acta Crystallogr.,

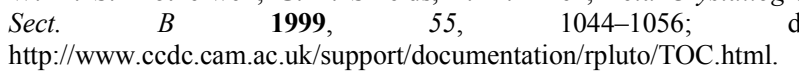

[37] a) T. M. Klapötke, K. Karaghiosoff, P. Mayer, A. Penger, J. M. Welch, Propell. Explos. Pyrotech. 2006, 31, 188-195; b) V. Ernst, T. M. Klapötke, J. Stierstorfer, Z. Anorg. Allg. Chem., 2007, 633, 879-887.

[38] a) M. Göbel, T. M. Klapötke, Z. Anorg. Allg. Chem. 2007, 633, 1006 1017 ; b) C. Darwich, T. M. Klapötke, C. Miró Sabaté, Chem. Eur. J. 2008, 14, 5756-5771; c) T. M. Klapötke, C. Miró Sabaté, Chem. Mater. 2008, 20(11), 3629-3637.

[39] J. Köhler, R. Meyer, Explosivstoffe, 7th ed., Wiley-VCH, Weinheim, Germany, 1991.

[40] a) H. D. B. Jenkins, D. Tudela, L. Glasser, Inorg. Chem. 2002, 41, 2364-2367; b) H. D. B. Jenkins, H. K. Roobottom, J. Passmore, L. Glasser, Inorg. Chem. 1999, 38, 3609-3620.

[41] H. Gao, C. Ye, C. M. Piekarski, J. M. Shreeve, J. Phys. Chem. 2007, C111, 10718-10731.

[42] M. Suceska, Propell., Explos., Pyrotech. 1991, 16, 197-202.

[43] J. Akhavan, The Chemistry of Explosives, $2^{\text {nd }}$ ed. RSC Paperbacks: Cambridge, UK, 2004.

[44] H. Gao, Z. Zeng, B. Twamley, J. M. Shreeve, Chem. Eur. J. 2008, 14, $1282-1290$. 
[45] UN Recommendations on the Transport of Dangerous Goods, Manual of Tests and Criteria., 4th ed.; United Nations: New York, 2003.

[46] http://www.systag.ch.

[47] ICT-Thermodynamic Code, Version 1.0, Fraunhofer-Institut für Chemische Technologie, Pfinztal, Germany, 1988-2000; R. Webb, M. van Rooijen, Proceedings of the 29th International Pyrotechnics Seminar, Westminster, CO, 2002.

[48] a) J. Thiele, Justus Liebigs Ann. Chem. 1892, 270, 54-63; b) J. Thiele, J. T. Marais, Justus Liebigs Ann. Chem. 1893, 273, 144-160; c) J.
Thiele, Ber. 1893, 26, 2645-2646; d) J. Thiele, Justus Liebigs Ann. Chem. 1898, 303, 57-75. 


\section{Entry for the Table of Contents}

The potential of the guanylurea cation $\left(\left[\mathrm{C}_{2} \mathrm{H}_{7} \mathrm{~N}_{4} \mathrm{O}\right]^{+}\right.$, see figure) to form energetic salts was explored by synthesizing, characterizing and testing a new family of compounds with promise as a new class of insensitive, low energy monopropellants with high thermal stabilities.

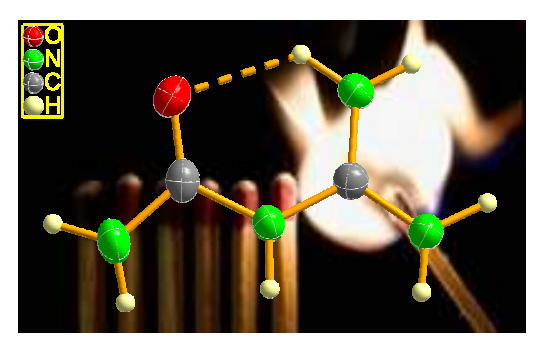

Energetic Materials

T. M. Klapötke*,

C. Miró Sabaté........ Page XX-XX

Low Energy Monopropellants Based on the Guanylurea Cation

Keywords: Guanylurea / Energetic / X-ray diffraction / DFT calculations 